\title{
Apparent Polar Wander Path for Adria \\ extended by new Jurassic paleomagnetic results from its stable core: tectonic implications
}

Emő Márton ${ }^{1}$, Dario Zampieri ${ }^{2}$, Vlasta Ćosović ${ }^{3}$, Alan Moro ${ }^{3}$, Katica Drobne ${ }^{4}$

${ }^{1}$ Geological and Geophysical Institute of Hungary, Palaeomagnetic Laboratory, Columbus 1723, $\mathrm{H}-1145$ Budapest, Hungary

2 Department of Geosciences, University of Padova, Via Gradenigo 6, 35131 Padova, Italy

${ }^{3}$ Department of Geology, Faculty of Sciences, University of Zagreb, Horvatovac 102a, 10000 Zagreb, Croatia

${ }^{4}$ Ivan Rakovec Institute of Paleontology, ZRC SAZU, Novi trg 2, SI-1000 Ljubljana, Slovenia 


\begin{abstract}
As a continuation of a systematic paleomagnetic research in the northern part of stable Adria, which provided a well-defined apparent polar wander (APW) path for the CretaceousEocene, we present new paleomagnetic results for the Jurassic. These new data were obtained from 15 geographically distributed localities from the Trento platform (eastern Southern Alps) using standard paleomagnetic approach. The Lower Jurassic shallow water carbonates are not considered for tectonic interpretation, due to inconsistent inclinations. The Middle and Upper Jurassic Rosso Ammonitico provided excellent kinematic constraints. With the new Jurassic results, an APW is now defined for Adria for the 167-40Ma interval. It is well constrained for timing of important changes, like the speed and the sense of rotations. This APW suggests that the CW rotation and southward shift changed to the opposite at $155.1 \pm 5.3 \mathrm{Ma}$, signifying a dramatic change in the life of the Neo-Tethys, from opening to closing. The latter is manifested in fast CCW rotation and northward movement of Adria up to $102.9 \pm 2.4 \mathrm{Ma}$ and moderate displacements in the same manner in post-103 Ma times. Combined data sets from stable Istria and the foreland of the Southern Alps point to an approximately $15^{\circ} \mathrm{CW}$ rotation with respect to Africa at the end of the Cretaceous, and an about $25^{\circ}$ in the CCW sense, after the Eocene.
\end{abstract}

Keywords:

Stable Adria; 167-41 Ma Apparent Polar Wander; Tectonic Implications 


\section{Introduction}

In the late 1970s and early 1980s the hot topic in the Alpine-Mediterranean paleomagnetism was the relationship of tectonic units, considered on geological background to be of African origin, to the African plate. The targets of the pioneering paleomagnetic studies were the Mesozoic rocks in the Adriatic "autochthon", like Gargano (Channell, 1977, VandenBerg, 1983) and stable Istria (Márton and Veljović, 1983), in the fold and thrust belts surrounding the "authochton", like the Southern Alps (e.g. VandenBerg and Wonders, 1980), the Umbrian Apennines (e.g. Channell et al., 1978, Cirilli et al., 1984) and in units not connected today to stable Adria, like the Transdanubian Range of the Pannonian Basin (Márton and Márton, 1981, 1983). A common feature of the paleomagnetic results obtained for all the above areas was proof for CCW rotations with respect to North and considered as evidence for Adria to have an African affinity. At that time the African Apparent Polar Wander path (APW) was poorly defined by direct data. For this reason „pseudo-African APWs” were constructed (e.g. VandenBerg, 1983 and Márton and Márton, 1983). These APWs featured slow and smooth displacements of the African plate. However, very fast movements were discovered for the Late Jurassic - Early Cretaceous of the Transdanubian Range (Márton and Márton, 1983) and later recognized for the Southern Alps (Channell 1996) and for the Apennines (Cirilli et al., 1984, Satolli et al., 2007, 2008). Thus, one of the problems became to find out if the APW for the Adriatic "autochthon" reflects the fast displacements indicated in the mentioned Africa- derived units or it is akin to any of the published African APWs, particularly to the more recently published ones (e.g. Besse and Courtillot, 2002, 2003, Torsvik at al., 2012, Muttoni et al., 2013) based on a much larger data set than the earlier versions.

Concerning the main issue of the 1980 ', to test Argand's model of African promontory (Argand, 1924), the pioneering studies were of limited value, partly because of contradictory results from Gargano (Channell, 1977, VandenBerg, 1983) partly due to poor statistical parameters of some data from the weakly magnetized platform carbonates from Istria (Márton and Veljović, 1983).

Due to the lack of high quality paleomagnetic results from the stable core of Adria, there were attempts to substitute them by data obtained from its folded/thrusted margins. While 

extended by new Jurassic paleomagnetic results from its stable core: tectonic implications.

Tectonophysics 700-701, 1-18.

it has been obvious that the displacements of Adria would be best constrained by paleomagnetic data from its stable core, the studies were handicapped by the limited extent of the outcrops, since "autochthonous" Adria is mostly covered by the Adriatic Sea. Moreover, the largest outcrop, Apulia, offers Cretaceous and younger strata of poor paleomagnetic properties. Thus the results obtained from Apulia (e.g. Speranza and Kissel, 1993, Márton and Nardi, 1994, van Hinsbergen et al., 2014) are few and do not provide as tight kinematic constraints for the southern part of stable Adria as the paleomagnetic studies of the foreland of the Southern Alps and stable Istria do for the northern part. This has been already documented for the Cretaceous and the Eocene (Márton et al., 2003, 2008, 2010, 2011).

In this paper we present new results for the Jurassic of the foreland of the Southern Alps (area D in Fig. 1). With the new results the APW for the northern part of Adria covers the time period from 167 to $41 \mathrm{Ma}$ and offers a solid data set for discussing the displacements of the largest crustal block of the Central Medierraneum in post-Triassic times

\section{New Jurassic paleomagnetic results from the Adige embayment}

\subsection{Geological settings}

The Southern Alps are a typical example of a deformed passive continental margin (e.g. Bertotti et al., 1993). The structure is the result of complex tectonic deformation, reworking inherited weaknesses in a changing geodynamic framework. In Mesozoic times the opening of the Alpine Tethys linked to the west to the opening of the north Atlantic, led to formation of passive margins (respectively European to the west and Adriatic to the east) (Bernoulli and Jenkyns, 1974; Winterer and Bosellini, 1981). The portion of margin now exposed in the Southern Alps developed on the Adriatic continental upper plate (Argand's African promontory), where shallow to deep marine carbonates were deposited during Mesozoic and Paleogene.

The continental rifting started in the Late Triassic and ended in the Middle Jurassic, when the Mesozoic ocean begun to spread (drifting). During the Norian, a widespread carbonate shelf 

extended by new Jurassic paleomagnetic results from its stable core: tectonic implications.

Tectonophysics 700-701, 1-18.

existed across Europe and Africa (Dolomia Principale/Hauptdolomit). Since the Late Norian the thick peritidal succession deposited on this shelf begun to fragment along normal faults from the Lake Lugano to Lake Garda, the area that shortly after became the Lombardian basin. During the Early Jurassic the rifting led to the development of horsts separated by graben or half-graben basins (Sarti et al., 1993). From the west to east the main paleogeographic units were the Lombardian basin, the Trento (Venetian) platform, the Belluno basin and the Friuli platform, all controlled by syn-sedimentary normal faults, mainly trending north-south.

The Trento platform covered a wide area and was part of a large system of shelfs that spread from Slovenia to the central Apennines. The Trento platform is now exposed in the Southern Alps. Its northern boundaries are unknown because it is not preserved north to the Periadriatic Lineament (Fig. 1), while well data testify that it extends beneath the Po Plain. From its paleogeographic evolution two main stages can be recognized (Fig. 2): a first stage of shallow water sedimentation represented by the thick pile of the Calcari Grigi and San Vigilio Oolite groups (Early Jurassic) and a second stage of pelagic sedimentation over the drowned Trento platform (Trento plateau) represented by the Rosso Ammonitico Veronese Formation (Middle-Late Jurassic). In the latest Jurassic a change in the oceanic currents led to the sedimentation of the white micritic limestones of the Maiolica (Late Tithonian- late Barremian), the marls of the Scaglia variegata alpina (Aptian-Cenomanian), and finally the hemipelagic marly limestones of the Scaglia rossa Formation (Late Cretaceous).

The Calcari Grigi Group encompasses the shallow water sediments deposited on the Trento Platform from the Hettangian to the Pliensbachian. It is composed of three formations (Fig. 2): the M. Zugna Formation (Hettangian-Sinemurian p.p.), the Loppio Oolitic Limestone Formation (Sinemurian p.p.) and the Rotzo Formation (Sinemurian p.p.-Pliensbachian). The Monte Zugna Formation comprises a pile of lagoonal muds (subtidal unit) and wackestones (peritidal unit) with a thickness of 300-500 m (Romano et al., 2005). The Loppio Oolitic Limestone is a 20 to $100 \mathrm{~m}$ thick grainstone body representing a sharp ingression of the oolitic sands from the western margin of the platform. The Rotzo Formation is interpreted as a carbonate ramp lagoonal depositional system (Masetti et al., 2012) and shows strong thickness variations (from 0 to several hundred metres) controlled by syn-sedimentary faults (Zampieri and Massironi, 2007; Franceschi et al. 2014). The typical lithologies are subtidal marls with large bivalves mounds (Lithiotis facies) (Bosellini and Broglio Loriga, 1971). The 
Márton, E., Zampieri, D., Ćosović, V., Moro, A., Drobne, K., 2017: Apparent Polar Wander Path for Adria extended by new Jurassic paleomagnetic results from its stable core: tectonic implications.

Tectonophysics 700-701, 1-18.

Lithiotis Fauna (Lithiotis, Coclearites and Lithioperna) is the first example of globally distributed mound-building bivalves in the geological record and experienced global diffusion in the Early Jurassic possibly linked to the aftermath of the SinemurianPliensbachian boundary negative C-isotope perturbation and to the opening of the Hispanic Corridor as a consequence of break up of Pangea (Franceschi et al., 2014). To the west, oolitic limestones are found, overlying the Rotzo Formation (Massone Oolitic Limestone) and are interpreted as oolitic shoals bordering the platform towards the Lombardian basin. In the same area the Calcari Grigi Group is unconformably overlain by the Tenno Formation (Lower Toarcian). This hemipelagic unit of marly and cherty limestones records the Toarcian oceanic anoxic event on the Trento platform (Woodfine et al., 2008). The Tenno Formation is followed by the grainstones of the S. Vigilio Group (Upper Toarcian-Aalenian?), which testifies for the presence of a re-established margin at the western border of the platform.

A new and generalized drowning of the Trento platform occurred at the end of the Aalenian, possibly in conjunction with an eutrophication of the shallow water environments (Zempolich, 1993). The Trento platform then became a submerged plateau, on top of which the Rosso Ammonitico Veronese (RAV) deposited (Bajocian p.p. - Tithonian p.p., Sturani, 1964). The RAV may be subdivided into several members characterized by different lithologies, age and degree of lateral continuity (Fig. 2). The different facies have been linked to the hydrodynamics of the currents (thinnest and early cemented successions on the submarine highs, thickest and less cemented in lows) on a sea floor topography controlled by syn-sedimentary tectonic activity (Martire et al., 2006). Where the RAV succession is complete, it is composed of three subunits. The Lower RAV (Upper Bajocian-Lower Callovian) overlies an unconformity represented by thin patches and small neptunian dikes of pelagic-rich grainstones and breccias (Posidonia alpina beds) (Sturani, 1971). The Lower RAV is composed of red nodular oncolitic-stromatolitic facies with several hard-grounds. The second sub-unit, the Middle RAV (Upper Callovian-Middle Oxfordian), is generally bounded by a hiatus at the base and at places a hiatus at the top. In the western portion of the plateau, it is composed of few metres of cherty limestones alternating with clays. The third sub-unit, the Upper RAV (Oxfordian-Upper Tithonian), is a nodular, stromatolitic red limestone. The nodules are considered an early diagenetic feature and consist of packstones with Saccocoma fragments and peloids. The nodules are separated by a darker and clayey 
Márton, E., Zampieri, D., Ćosović, V., Moro, A., Drobne, K., 2017: Apparent Polar Wander Path for Adria extended by new Jurassic paleomagnetic results from its stable core: tectonic implications.

Tectonophysics 700-701, 1-18.

matrix, bearing evidence of strong pressure dissolution, with fitted fabrics and thick dissolution seams.

Overall, the RAV Formation is no more than $30 \mathrm{~m}$ thick and represents about $21 \mathrm{Ma}$, therefore, it is considered strongly condensed (Martire and Clari, 1994; Martire, 1996). This condensation is attributed to gaps in the sedimentation and to early diagenetic mechanical and chemical compaction. Due to the different petrographic composition of the pseudonodular facies of the Lower RAV with respect to the nodular facies of the Upper RAV, the mechanical and chemical compaction was less effective in the Lower RAV (38\%) and more effective in the Upper RAV (70\%). However, the highest compaction values (60-70\%) were obtained in the Middle RAV, (Clari and Martire 1996), characterized by thin-bedded mud-supported bivalve wackestone facies.

The overlying Maiolica Formation (Upper Tithonian-Barremian) comprises thin-bedded cherty pelagic micrites $250 \mathrm{~m}$ thick, and marks the maximum deepening of the area. The alternating limestone/marlstone sediments of the subsequent Scaglia Variegata Alpina are bounded by two black-shale layers localized few metres above the base and at the top of the formation. The black-shales correlate with the Oceanic Anoxic Events (OAE 1 and 2) documented in many basins around the globe (Schlanger and Jenkyns, 1976). The marly limestones of the Scaglia rossa (Turonian-Maastrichtian) Formation deposited during the inversion of the basins.

During the Neogene contraction of the Southern Alps the steep syn-sedimentary faults bounding the basins were reactivated as strike-slip or transpressional faults. A notable example of large-scale structure controlled by the Jurassic palaeostructure is the Giudicarie belt (Fig. 1), a transpressional belt oblique to the Southern Alps belt resulting from oblique inversion of the margin (Garda escarpment) between the Lombardian basin and the Trento platform (Castellarin, 1972). The southern part of the outcropping Trento platform corresponds to the triangular shaped Lessini Mountains block, which is interpreted as the "undeformed" foreland of the Southern Alps (Bigi et al., 1990; Fantoni and Franciosi, 2009) and thus part of the autochthonous core of the Adriatic plate (Fig. 1).

\subsection{Paleomagnetic sampling}


Márton, E., Zampieri, D., Ćosović, V., Moro, A., Drobne, K., 2017: Apparent Polar Wander Path for Adria extended by new Jurassic paleomagnetic results from its stable core: tectonic implications.

Tectonophysics 700-701, 1-18.

The Jurassic samples for this paleomagnetic study were collected from the Lessini Mts. In this area the Mt. Zugna and Loppio Formations (Fig. 2) were unsuitable for paleomagnetic study since they are composed of dolomitized or porous carbonate rocks (Masetti et al., 2012), heavily fractured at some places by syn-sedimentary extensional tectonics. The oldest rocks drilled in this study belong to the Rotzo Formation (grey mudstone, locality 15, Figs 2 and 3). The Tenno Formation (Fig. 2) was sampled in an artificial fresh cliff along a road just north of the Bosco-Chiesanuova village, which exposes grey hemipelagic limestone with white cherts (locality 14, Figs 2 and 3). From the S. Vigilio group (Fig. 2) we sampled finegrained grey grainstone beds (Ronconi, locality 13, Figs 2 and 3) and crinoidal packstones directly underneath the Lower RAV (Tracchi, locality 12, Figs 2 and 3).

In the Lessini Mts the three units of the RAV Formation can easily be recognized on the basis of sedimentological features. The Lower RAV overlies the S. Vigilio Group with an abrupt discontinuity surface associated with a gap of minimum $5 \mathrm{Ma}$ (Clari et al., 1995, Fig. 2). From this formation we sampled massive, pseudo-nodular limestones (localities 5-11, Figs 2 and 3). The Middle RAV (Fig. 2) is separated from the Lower RAV by a discontinuity surface associated with a middle Callovian to lower Oxfordian gap (Clari et al., 1990). This unit was not sampled by us, due to scarce exposures. However, some outcrops were earlier studied by Channell et al. $(1990,2010)$, and their results will be evaluated together with those of the present study. From the Upper RAV we sampled localities 1-4 (Figs. 2 and 3).

Biostratigraphic constraints on the sampled localities were assigned by bibliography and by micropaleontological study of thin sections prepared from hand samples collected from the respective localities at the time of paleomagnetic sampling. In the Early Jurassic units the main taxa used are foraminifers and palynomorphs; Middle Jurassic units are dated using bivalve filaments, crinoids and foraminifers whereas radiolarians, foraminifers and Saccocoma allow the dating of the Late Jurassic units (Fig. 2).

At the above mentioned localities several cores were drilled from different beds, often of different colours and oriented in situ with a magnetic compass.

\subsection{Laboratory processing of the oriented samples}

The drill cores were cut into standard size specimens. The natural remanent magnetization (NRM) and the susceptibility were measured in the natural state using JR-4 and JR-5A 

extended by new Jurassic paleomagnetic results from its stable core: tectonic implications.

Tectonophysics 700-701, 1-18.

spinner magnetometers and a KLY-2 kappabridge, respectively. Sister specimens from each locality were selected for detailed stepwise demagnetization till the NRM signal was lost, one with alternating field (AF), the other with thermal method. Based on the behaviour of the selected samples, the remaining samples from the respective localities were demagnetized with one of the methods or the combination of the two in several steps. During thermal demagnetization possible mineralogical changes were monitored by remeasuring the susceptibility after each demagnetization step. The demagnetization curves were analysed for linear segments and the line going to the origin was interpreted as characteristic remanence and used for statistical evaluation on locality level. Magnetic mineralogy experiments included isothermal remanence (IRM) acquisition experiments (Molspin pulse magnetizer) and the thermal demagnetization of the three-component IRM (Lowrie, 1990), accompanied by susceptibility monitoring. In order to check possible inclination flattening, anisotropy of the remanence (AARM) was determined (LDA-3A and AMU-1A instruments) on several specimens.

\subsection{Results}

The platform carbonates (localities 12-15, Figs 2 and 3) have mostly diamagnetic susceptibilities and weak NRM intensities, even before demagnetization (max $90 \mu \mathrm{A} / \mathrm{m}$ ). The low NRM intensity $(6 \mu \mathrm{A} / \mathrm{m})$ explains the complete failure to obtain interpretable demagentization diagrams for locality 14 . In contrast, the demagnetization curves were well defined for localities 12, 13 and 15 (Fig. 4, specimens SA1298B and SA1228B) from which locality mean paleomagnetic directions were calculated (Table 1).

The Rosso Ammonitico samples have weak positive susceptibilities, mostly in the $10^{-5} \mathrm{SI}$ range. The initial NRM intensities are in the $10^{-3} \mathrm{~A} / \mathrm{m}$ range. The demagnetization behaviour of the Rosso Ammonitico is very good. The NRM in most cases is composite (although single component remanence was also observed, like SA1136A), but the overprint component is easily removed (Figs. 4 and 5). Red or pink samples from the same locality, where applicable, have higher NRM intensities than the white ones. Nonetheless, the behaviour of the specimens of different colours on AF and thermal demagnetizations is very similar (e.g. locality 2, Fig. 5). It is interesting to note that the NRM decays completely by the Curie point of the magnetite both in the red and in the white samples, i.e. the red pigment does not 

extended by new Jurassic paleomagnetic results from its stable core: tectonic implications.

Tectonophysics 700-701, 1-18.

contribute to the NRM. The polarity may be independent of the colour (e.g. locality 2) or samples of different colours have different polarities (e.g. locality 6, in Fig. 6, where white samples have reversed, red ones normal polarity). The reversal test, when applicable, suggests that the different polarities must be due to the polarity reversal of the Earth magnetic field during deposition/early diagenesis. The only exception is locality 7, (Fig. 3) where a huge quarry was drilled at three points. The characteristic remanent magnetizations (ChRM) cluster at each of them, but the clusters are distributed along a great circle, which passes close to the locality mean directions of the coeval localities (after tilt corrections). The ChRM at point SA1292-297 is obviously a composite one, in which the normal and reversed polarity components are balanced (Fig. 7).

Thermal demagnetization of the NRM already implied that magnetite was the main carrier of the ChRM, although moderate contribution from maghemite can inferred occasionally (e.g. Fig. 4, SA1310B, decreasing susceptibility on heating from $250^{\circ} \mathrm{C}$ on). IRM acquisition characteristics show the dominance of fast saturating magnetic mineral(s), as $73-94 \%$ of the IRM at $1.0 \mathrm{~T}$ is acquired at $0.12 \mathrm{~T}$. (Fig. 8). All components of the IRM decay by the Curie point of the magnetite, independently of the proportion of the slowly saturating phase (Fig. 9).

Remanence anisotropy (AARM) experiments were made to find out if the obtained inclinations could have been flattened by compaction. For most localities the degree of the AARM anisotropy was below five percent (Fig. 10), therefore correction was not necessary (Stephenson et al., 1986). For localities 2 and 3 (Table 1) the degree somewhat exceeded 5\% (Fig. 10), yet inclination flattening was unlikely because of the high angle between the AARM foliation plane and the bedding plane (Jackson et al., 1991, Kodama 2009).

\subsection{Discussion of the new Jurassic paleomagnetic results}

The locality mean paleomagnetic directions (Table 1) are statistically well-defined, significantly depart from the direction of the present Earth magnetic field at the sampling area, before tectonic correction, which is the evidence for long-term stability of the paleomagnetic signal. The locality mean directions for the Early Jurassic platform carbonates exhibit highly consistent declinations, but very different inclinations after tilt corrections (Table 1, localities 12, 13 and 15). The latter can not be attributed to inclination flattening, for the degree of the AARM is far below $5 \%$. Although the overprint component seems to be 

extended by new Jurassic paleomagnetic results from its stable core: tectonic implications.

Tectonophysics 700-701, 1-18.

removed on demagnetization (Fig 4, specimens SA1298b and 1228b), we can not exclude unremovable overprint responsible for the inconsistent inclinations. In contrast, the coeval paleomagnetic locality mean directions cluster for the Middle and Upper Jurassic, respectively. The acquisition of their ChRMs must be close to the age of the sedimentation for the following reasons. 1. Within-locality (Table 1, where applicable) and between-locality (Table 3) reversal tests are significant (McFadden and McElhinny, 1990, classification B for both the Lower and Upper RAV). This alone is often regarded as evidence for primary ChRM, especially short of fold/tilt test, when single locality results are interpreted in terms of tectonics (e.g. van Hinsbergen al., 2014) 2. On tilt corrections the overall mean paleomagnetic directions remain practically the same, with considerably improving statistics after corrections (Fig.11), despite of the very shallow bedding tilts. The sampled strata are not folded, only tilted during Paleogene extension. This extension was intensive around the Trento platform, but produced only a system of ca. N-S trending normal faults and very moderate tilts in the platform itself (Zampieri, 2000). This type and intensity of the deformation is very unlikely to affect the remanence. 3. The remarkably high degree of regional consistency of the tilt corrected paleomagnetic directions for the Lower and Upper RAV, respectively (Fig. 11) and their significant difference are also considered as supports for the primary nature of the ChRMs.

The Middle (Lower RAV) and Late (Upper RAV) Jurassic poles of the present study are well constrained, both in time and in statistical terms. It means that the earlier defined APW for northern Stable Adria (Márton et al., 2010, 2011) can be extended towards older ages. The gap between the Lower and Upper RAV, can also be filled since some data of "Middle RAV age" (items $79-82$ in Table 2) by Channell et al. $(1990,2010)$ do represent the foreland of the Southern Alps (Fig. 3). 


\section{The 167-41Ma APW for northern Stable Adria}

The new APW for Adria is based on high quality paleomagnetic results from the Adige embayment and stable Istria (Table 2). The two sampling regions are characterized by different lithologies. In the Adige embayment mostly pelagic, in Istria platform sediments were studied. The reliability of the APW is due to the following facts: 1) the paleomagnetic poles (Table 3 ) are based on geographically distributed localities of similar ages (on average, eight localities per pole), 2) the source rocks are precisely dated by biostratigraphic methods, 3) there are constraints on the age of the magnetization (tilt and/or reversal tests), 4) inclinations are corrected for flattening, where necessary (Márton et al., 2010a and present paper). Such correction was not applied for the platform carbonates, where early diagenesis prevents compaction and accordingly, the AARM anisotropy is very low, (e. g. Fig. 10). The Lower and Upper Rosso Ammonitico and Maiolica samples do not need correction either, since the degree of AARM is normally below $5 \%$, or when it is somewhat higher, the magnetic foliation plane makes a high angle with the bedding plane (examples for Upper RAV are in Fig. 10). The Scaglia Rossa samples needed correction for inclination flattening (compare the measured and corrected inclinations in Table 2 items 21-23, 25-35, 41-44, the method was described by Márton et al., 2010) and correction was also applied for a Middle RAV locality (Table 2, item 82, method was described by Muttoni et al., 2013).

The paleomagnetic poles for different age groups are shown in Table 3, based on localities as well as on samples. The first method is the usual one in the paleomagnetic literature and this is the method the authors of the present paper prefer and practice when the issue is the large scale displacement of a tectonic unit. The reason is that results from a single locality can be biased by local effects e.g. unremovable overprint (which can be, in the worst case, complete remagnetization), or imperfect tectonic correction (e.g. error in the dip measurement, uncorrected-for plunge). Such factors would worsen the statistical parameters of an overall-mean direction, but a bias due to these factors will be minimalized when the locality mean direction from several geographically distributed localities enter the calculation as equivalents. The second method was recently recommended by van Hinsbergen et al. (2014) who argued that localities represented by larger number of samples are more reliable than those with smaller. This approach obviously reduces the size of $\alpha_{95}$ 
Márton, E., Zampieri, D., Ćosović, V., Moro, A., Drobne, K., 2017: Apparent Polar Wander Path for Adria extended by new Jurassic paleomagnetic results from its stable core: tectonic implications.

Tectonophysics 700-701, 1-18.

(Table 3 and Fig. 12), which in its turn influences the tectonic interpretation. This is particularly true when decision is made about relative movement between tectonic units on statistical grounds by comparing only a pair of coeval poles, instead of longer segments of the APWs, where systematic deviations or the lack of it may become obvious.

The APW for Northern Adria, based on direct data comprises 12 paleomagnetic poles (Table 3 and Fig. 12, the ages in $\mathrm{Ma}$ are referred to International Chronostratigraphic Chart v2016/12, Cohen et al., 2013 updated). It starts at 167.3 $\pm 2.1 \mathrm{Ma}$, when the basin conditions change from shallow water to pelagic. The APW displays a hairpin between $167.3 \pm 2.1$ and $102.9 \pm 2.4 \mathrm{Ma}$, with a turning point at $155.1 \pm 5.3 \mathrm{Ma}$. Latitudinal velocities and angular rotations calculated from the APW reveal that between $167.3 \pm 2.1$ and $155.1 \pm 5.3 \mathrm{Ma}$ (during the deposition of RAV) Adria moved southward with a nearly constant speed of $10 \mathrm{~cm} / \mathrm{year}$

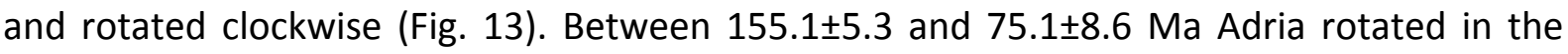
CCW sense and the net latitudinal movement was northward. The latter was very fast between $155.1 \pm 5.3$ and $143.6 \pm 3.8 \mathrm{Ma}$, during the deposition of the Maiolica facies. Similar hairpin was reported for the Lombardian basin, belonging to the thrusted margin of Adria with a minimum paleolatitude of about $10^{\circ}$ around 154Ma (Channell et al., 2010), and the dramatic Mesozoic Alpine sedimentary facies changes were correlated with the latitudinal movements of Adria (Muttoni et al., 2005).

The hairpin-like feature, in the APW, documented by independent studies can be interpreted as the paleomagnetic manifestation of the final stage of the opening and the initial closing of the Neo-Tethys. The paleomagnetic dating of the turning point harmonizes with tectonic observations from the South Alpine rifted margin of the Neo-Tethys, which has experienced extension until 157Ma (Bertotti et al., 1993). It seems, therefore, that rifting was still active in the South Alpine margin, when the Pindos-Vardar basin was already in the initial stage of the closure from about 165Ma (Dimo-Lahitte et al., 2001, Maffione et al., 2015).

The polar movement considerably slows down after the Early Albian, following a hiatus in sedimentation (Márton et al., 2011), due to emergence of the platform (Istria) and subaqueous denudation in the basin (Adige embayment) probably connected to an important tectonic event. Between 102.9 \pm 2.4 and $85.8 \pm 2.2 \mathrm{Ma}$ Adria seems to have changed latitudes very fast. During a short time such movement is difficult to conceive as relevant to plate tectonic movements. It is more reasonable to calculate with a moderate net southward drift between 102.9 \pm 2.4 and $97.2 \pm 3.3 \mathrm{Ma}$ (as the time averaged latitude suggests), followed 

extended by new Jurassic paleomagnetic results from its stable core: tectonic implications.

Tectonophysics 700-701, 1-18.

by a period of latitudinal stability, which lasted till 52.2 $\pm 4.4 \mathrm{Ma}$ (Fig. 13). Concerning the

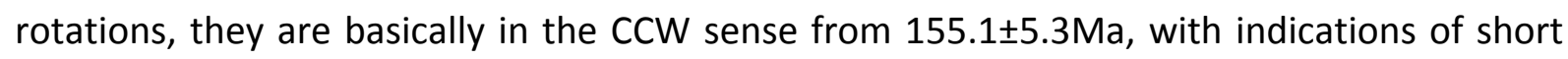
periods of $\mathrm{CW}$ rotations between $102.9 \pm 3.3$ and $97.2 \pm 33 \mathrm{Ma}$ and $85.8 \pm 2.2-40.9 \pm 7.0 \mathrm{Ma}$, respectively.

After 40Ma we do not have direct constraint for the displacements for the northern part of Adria. However, to reach the present north pole, CCW rotation accompanied by northward movement of Adria is required (Fig. 13).

\section{The Adria-Africa relationship reflected in the respective APWs}

The new APW for Adria is compared with two widely accepted synthetic APWs for Africa (Besse and Courtillot, 2002, 2003, and Torsvik et al. 2012), and a combined African-South Alpine APW (Muttoni et al., 2003), respectively. The synthetic APWs were developed using different data sets, different reconstructions of the plate configurations and different methods of smoothing the APW. Muttoni et al. (2013) regarded the thrusted Southern Alps attached to the African plate from 250Ma on, and thus combined data from the two.

Declinations calculated for a common latitude/longitude from the synthetic reference APWs considerably differ for pre-130Ma times (Figs. 14) and also from that for the northern part of stable Adria. On the other hand the latter parallels that of the combined African - South Alpine declination curve (Fig. 15). The paleolatitude patterns are more consistent, except for the extremely low paleolatitude about 155Ma (Figs. 14 and 15) both for the thrusted Southern Alps and stable Adria, a feature which is not seen from the "synthetic" paleolatitude curves (Fig. 14). This observations suggest that, Adria must have been a microplate, moving independently of Africa between 167 and 130Ma. Independent Adria microplate after the Jurassic was inferred from paleomagnetic (Westphal et al., 1986) and geological (e.g. Ricou et al., 1986) observations. Platt et al. (1989) also argued for an independent Adria. To others, Adria was an integral part of the African plate during the Mesozoic (e. g. Channell et al., 1979, Catalano et al., 2001; de Lamotte et al., 2011; Gallais et al., 2011; Speranza et al., 2012, Rosenbaum et al., 2004). Wortman et al., (2001) discussed 
Márton, E., Zampieri, D., Ćosović, V., Moro, A., Drobne, K., 2017: Apparent Polar Wander Path for Adria extended by new Jurassic paleomagnetic results from its stable core: tectonic implications.

Tectonophysics 700-701, 1-18.

the problem of Adria in the context of the development of the Alpine Tethys and concluded that "independent movement of Adria during Jurassic/Cretaceous times is not a necessity". It seems that the issue remains open also from paleomagnetic point of view until the reference APW for Africa becomes better defined by African paleomagnetic data.

In post-130Ma, paleodeclinations curves computed from the synthetic APWs and the one by Muttoni et al., (2013) provide a robust reference frame for Adria. They suggest that Africa continues to rotate in the CCW sense, which is manifested in decreasing westward deviation of the paleodeclinations from North (Fig. 14). In stable Adria, before and after a hiatus in sedimentation (hiatus 3, Fig. 14) robust data sets show that the orientation of Adria remains basically the same (Fig. 16). This implies decoupling of Adria from Africa with a CW rotation. It is important to note that reliable paleomagnetic results, both from northern and southern Adria, suggest decoupling from Africa by CW rotation. This interpretation is supported by mostly single locality Cretaceous declinations from Apulia which follow the "northern Adriatic" trend (Márton and Nardi, 1994 , van Hinsbergen et al., 2014), on one hand and a number of Eocene paleomagnetic locality mean directions from the southern part of Adria, which were regarded by the authors of the results coeval with the stratigraphic age (Fig. 16b). Unfortunately, not all statistically acceptable results from Eocene rocks are suitable for constraining the coeval paleomagnetic pole, because the ChRMs represent widespread remagnetization (all the reversed polarity directions from Gargano, Speranza and Kissel, 1993) or due to the ambiguous origin of the remanence combined with uncertain origin of the non-horizontal position of the beds (tectonic or primary bedding dip, Tozzi et al., 1988).

Evidence for relative movement between Africa and Adria at the end of Cretaceous is not only inferred from paleomagnetic data, but was suggested e.g. by Platt et al. (1989) and Wortman et al. (2001). By using plate reconstructions in which Adria and Africa were coupled in Jurassic/Cretaceous times, Wortman et al. (2001) faced the "Adria space problem", i.e. a too easterly position of Adria if it is rotated forward in time using the African rotation parameters. Although if they produced a complex kinematic model under the assumption of a rigid connection between Adria and Africa, they stated that geophysical data support the idea of Adria being independent of Africa and the solving in this way the "Adria space problem" would require a clockwise rotation of Adria versus Africa.

When the Eocene paleomagnetic pole is calculated from locality mean paleomagnetic directions for the northern part of Adria, a total of $24.9 \pm 8.7^{\circ}$ post-Eocene $\mathrm{CCW}$ rotation 
Márton, E., Zampieri, D., Ćosović, V., Moro, A., Drobne, K., 2017: Apparent Polar Wander Path for Adria extended by new Jurassic paleomagnetic results from its stable core: tectonic implications.

Tectonophysics 700-701, 1-18.

(with respect to $\mathrm{N}$ ) is defined. By combining these data with those from the southern part of Adria, the angle will be $19.9 \pm 5.3^{\circ}$. Earlier Soffel (1978) postulated a CCW rotation for Adria on paleomagnetic grounds, close to the Eocene-Oligocene boundary. A CCW rotation for the Adriatic indenter during the latest Oligocene-early Miocene has been suggested by Malusà et al. (2016) on the basis of the detrital zircon U-Pb geochronology of the Adriatic foredeep turbidites. These sediments were derived from the erosional unroofing of the Lepontine dome (Garzanti and Malusà, 2008). The unroofing was triggered by the indentation of the Adriatic lithosphere beneath the Central Alps (Malusà et al., 2015). The rotation of Adria occurred in conjunction with right-lateral strike-slip movements along the Insubric fault (e.g. Schmidt et al., 1989) and the scissor-type opening of the Ligurian-Provençal basin and the CCW rotation of the Corsica-Sardinia block (Gattacecca et al., 2007). More recently an about $20^{\circ} \mathrm{CCW}$ rotation for Adria was calculated from the Eastward increasing shortening in the Alps during the last 20Ma (Ustaszewski et al., 2008).

Van Hinsbergen et al. (2014) calculated an angle of $9.8 \pm 9.5^{\circ} \mathrm{CCW}$ rotation at $20 \pm 10 \mathrm{Ma}$ of Adria relative to Africa. As described above, we can not agree with disregarding the possibility of independent movement of Adria from Africa in the late Jurassic-Early Cretaceous, suggested by van Hinsbergen et al. (2014) and provide an alternative interpretation for the Eocene data from the southern part of Adria. As effort to obtain Miocene paleomagnetic results from the northern stable part of Adria were not successful (Márton et al., 2011) and there are only single locality results from Apulia, we still are of the opinion, that the circum-Adriatic region is a key area in interpreting the Eocene data from stable Adria. In this region, the Upper Miocene basin sediments are known to have suffered strong compression (e.g. Bada et al., 1999, Fodor et al., 1998, Tomljenović and Csontos, 2001). Miocene sediments from several of such basins yielded evidence for CCW rotation of similar angle as the Paleocene-Eocene rocks in stable Adria (Márton, 2006 and references therein, Márton et al., 2011). As the tectonic inversion of the earlier extensional basins is attributed to northward moving Adria, we suggest that the rotations in the circum-Adriatic basins were induced by rotating Adria. This pinpoints the about $25^{\circ} \mathrm{CCW}$ rotation of Adria to the very end of the Miocene.

It is obvious from the above discussion that the concept of Adria as an African promontory in unchanged orientation relative to Africa, at least after the Early Maastrichtian, should be abandoned. The solution for the enigmatic differences between the APWs for Adria and the 
synthetic APWs by Torsvik et al. (2012) and/or Besse and Courtillot $(2002,2003)$ during the late Jurassic-Early Cretaceous needs analysis and considerations which are beyond the scope of the present study.

\section{General conclusions}

1. The APW for Adria defined by direct data from the northern stable part is now extending from the Middle Jurassic to the end of the Eocene. This APW makes proxies for stable Adria outdated.

2. The most conspicuous feature of the APW for the northern part of stable Adria is an extremely narrow and long hairpin, which is the consequence of a CW rotation accompanied by southward shift between 167.3 \pm 2.1 and 155.1 $\pm 5.3 \mathrm{Ma}$ and an opposite movement between $155.1 \pm 5.3$ and 102.9 $\pm 2.4 \mathrm{Ma}$. This feature constrains the most intensive period of the opening and closing of the Neo-Tethys. The closing process is also reflected with the same "intensity" in the paleomagnetic data from Apulia (van Hinsbergen et al., 2014) as well as from thrusted Southern Alps (Muttoni et al., 2013). The similar patterns of the Cretaceous paleodeclination curves for Adria and the thrusted Southern Alps imply co-ordinated movement between the two. The systematic deviations on the other hand, suggest postCretaceous large scale relative movement.

3. The paleodeclination curves calculated from synthetic APWs defined by Besse and Courtillot $(2002,2003)$ and Torsvik et al. (2012) for a common site are disagreement for most of the 167-103 Ma period. The paleodeclination curve for Adria, which is well constrained for timing of important changes concerning the speed, the sense of rotations does not fit either of them. The solution for the enigmatic differences between the APWs for Adria and the synthetic APWs either by Torsvik et al. (2012) or Besse and Courtillot (2002, 2003) during the late Jurassic-Early Cretaceous needs analysis and considerations which are beyond the scope of the present study. 

extended by new Jurassic paleomagnetic results from its stable core: tectonic implications.

Tectonophysics 700-701, 1-18.

4. The APW for Adria from direct data is not perfectly continuous, mainly due to longer than $5 \mathrm{Ma}$ stratigraphic gaps, signifying important tectonic events. The Aptian-Lower Albian one marks the time when the speed of the APW slowed down considerably, while the Latest Cretaceous-Paleocene gap marks the decoupling of Adria from Africa.

5. The Latest Cretaceous decoupling is manifested in an approximately $15^{\circ}$ deviation of the paleodeclinations for Adria with respect to the fairly well defined African paleodeclinations. The deviation is due to the continuing CCW rotation of Africa across the K/Pc boundary, while the orientation of Adria remained unchanged.

6. The Eocene paleomagnetic results form the northern part of stable Adria point to the second event of relative rotation with respect to Africa, suggesting that Adria rotated in the $\mathrm{CCW}$ sense about $25^{\circ}$ relative to Africa, after the Eocene.

7. The pre-latest Cretaceous paleomagnetic declinations for stable Adria are the resultant of two opposite rotations, a CW, followed by a larger CCW. Consequently, the pre-latest Cretaceous paleomagnetic declinations depart systematically to the west from the expected ones in an African framework.

\section{Acknowledgements}

The authors thank Guido Roghi (fieldwork), Roberta Romano (micropalentological analysis), Luca Martire and Marco Franceschi (discussions on the geological setting of the Lessini mountains). Constructive reviews by Marco Maffione and by an anonymous reviewer greatly improved this paper. This work was supported by the Hungarian Scientific Research Fund OTKA project no. K105245 and by the Università degli studi di Padova,Scientific Research funds, part EX 60\% 2013, 2014, 2015. 
References

Argand, E., 1924. La tectonique de I'Asie. Proc. 13th Int. Geol. Congr. Brussels, 7, 171-372.

Bada, G., Horváth, F., Gerner, P., Fejes, I., 1999. Review of the present day geodynamics of the Pannonian basin: progress and problems. Journal of Geodynamics $27,501-527$.

Bernoulli, D., Jenkyns, H. C., 1974. Alpine, Mediterranean and Central Atlantic Mesozoic facies in relation to the early evolution of the Tethys. In: Dott, R.H., Shaver, R.H. (Eds.), Modern and Ancient Geosynclinal Sedimentation SEPM Spec. Publ. 19, 129160.

Bertotti, G., Picotti, V., Bernoulli, D., Castellarin, A., 1993. From rifting to drifting: tectonic evolution in the South-Alpine upper crust from the Triassic to the Early Cretaceous. Sedim. Geol. 86, 53-76.

Besse, J., Courtillot, V., 2002. Apparent and true polar wander and geometry of the geomagnetic field over the last 200Myr. Journal of Geophysical Research 107 B11, EPM 6-1-6-31.

Besse, J., Courtillot, V., 2003. Correction to "Apparent and true polar wander and geometry of the geomagnetic field over the last 200Myr". Journal of Geophysical Research 108 B10, EPM 3-1-3-2.

Bigi, G., Cosentino, D., Parotto, M., Sartori, R., Scandone, P., 1990. Structural model of Italy. Sheet n. 1. In: Castellarin, A., Coli, M., Dal Piaz, G.V., Sartori, R., Scandone, P., Vai, G.B. (Eds.), Progetto Finalizzato Geodinamica, CNR, Roma.

Bosellini, A., Broglio Loriga, C., 1971. I "Calcari Grigi" di Rotzo (Giurassico inferiore, Altopiano di Asiago) e il loro inquadramento nella paleogeografia e nella evoluzione tettonicosedimentaria delle Prealpi Venete. Ann. Univ. Ferrara Nuova Ser. 9 (5/1), 1-61.

Castellarin, A., 1972. Evoluzione paleotettonica sin sedimentaria del limite tra "piattaforma veneta" e "bacino lombardo, a nord di Riva del Garda: Giornale di Geologia 38, 11212.

Castellarin, A., Vai, B., Cantelli, L., 2006. The Alpine evolution of the Southern Alps around the Giudicarie faults: A Late Cretaceous to Early Eocene transfer zone. Tectonophysics 414, 203-223.

Catalano, R., Doglioni, C., Merlini, S., 2001. On the Mesozoic Ionian basin. Geophys. J. Int. 144, 49-64.

Channell, J.E.T., 1977. Paleomagnetism of limestones from the Gargano peninsula (Italy) and the implication of these data. Geophys. J. R. astr. Soc. 51, 605-616. 

extended by new Jurassic paleomagnetic results from its stable core: tectonic implications.

Tectonophysics 700-701, 1-18.

Channell, J.E.T., 1996. Palaeomagnetism and palaeogeography of Adria. In: Morris, A., Tarling, D.H. (Eds.), Palaeomagnetism and tectonics of the Mediterranean region. Geological Society, London, Special Publications 105, 119-132.

Channell, J.E.T., Lowrie, W., Medizza, F., Alvarez, W., 1978. Palaeomagnetism and tectonics in Umbria, Italy. Earth and Planetary Science Letters 39, 199-210.

Channell, J. E. T., D’Argenio, B., Horváth, F., 1979. Adria, the African promontory in Mesozoic Mediterranean paleogeography. Earth-Science Reviews 15, 213-292.

Channell, J. E. T., Massari, F., Benetti, A., Pezzoni, N., 1990. Magnetostratigraphy and biostratigraphy of Callovian-Oxfordian limestones from the Trento Plateau (Monti Lessini, northern Italy). Palaeogeography, Palaeoclimatology, Palaeoecology 79, 289303.

Channell, J. E. T., Casellato, C. E., Muttoni, G., Erba, E., 2010. Magnetostratigraphy, nannofossil stratigraphy and apparent polar wander for Adria-Africa in the JurassicCretaceous boundary interval. Palaeogeography, Palaeoclimatology, Palaeoecology 293, 51-75.

Cirilli, S., Márton P., Vigliotti, L., 1984. Implications of a combined biostratigraphic and paleomagentic study of the Unbrian Mailolica formation. Earth and Planetary Science Letters 69, 203-214.

Clari, P.A., Martire, L., Pavia, G., 1990. L'Unità selcifera del Rosso Ammonitico Veronese (Alpi Meridionali). Atti Convegno „Fossili, Evoluzione, ambiente”, Pergola II 1987, 151-162.

Clari, P.A., Dela Pierre, F., Martire, L., 1995. Discontinuities in carbonate successions: identification, interpretation and classification of some Italian examples. Sedimentary Geology 100, 97-121.

Clari, P.A., Martire, L., 1996. Interplay of cementation, mechanical and chemical compaction in nodular limestones of the Rosso Ammonitico Veronese (Middle-Upper Jurassic, NE Italy). J. Sed. Res. 66, 447-458.

Cohen, K.M., Finney, S.C., Gibbard, P.L., Fan, J.-X. (2013; updated). The ICS International Chronostratigraphic Chart. Episodes 36, 199-204.

de Lamotte, F.D., Raulin, C., Mouchot, N., Wrobel-Daveau, J.C., Blanpied, C., Ringenbach, J.C., 2011. The southernmost margin of the Tethys realm during the Mesozoic and Cenozoic: initial geometry and timing of the inversion processes. Tectonics 30, TC3002.

Dimo-Lahitte, A., Monié, P., Vergély, P. 2001. Metamorphic soles from the Albanian ophiolites: Petrology, ${ }^{40} \mathrm{Ar} /{ }^{39} \mathrm{Ar}$ geochronology, and geodynamic evolution. Tectonics 20/1, 78-96.

Enkin, R., 2003. The direction-correction tilt test: an all-purpose tilt/fold test for paleomagnetic studies. Earth and Planetary Science Letters 212, 151-166. 
Fantoni, R., Franciosi, R., 2009. Mesozoic extension and Cenozoic compression in Po Plain and Adriatic foreland. Rend. Online Soc. Geol. It. 9, 28-31.

Fisher, R.A., 1953. Dispersion on a sphere. Proceedings of the Royal Society London 217, 295-305.

Fodor, L., Jelen, B., Márton, E., Skaberne, D., Čar, J., Vrabec, M., 1998. Miocene-Pliocene tectonic evolution of the Slovenian Periadriatic Line and surrounding area Implications for Alpine-Carpathian extrusion models. Tectonics 17, 690-709.

Franceschi, M., Dal Corso, J., Posenato, R., Roghi, G., Masetti, D., Jenkyns, H., 2014. Early Pliensbachian (Early Jurassic) C-isotope perturbation and the diffusion of the Lithiotis Fauna: Insights from the western Tethys. Palaeogeography, Palaeoclimatology, Palaeoecology 410, 255-263.

Gallais, F., Gutscher, M.A., Graindorge, D., Chamot-Rooke, N., Klaeschen, D., 2011. A Miocene tectonic inversion in the Ionian Sea (central Mediterranean): Evidence from multichannel seismic data. Journal of Geophysical Research 116, B12108.

Garzanti, E., Malusa', M.G., 2008, The Oligocene Alps: Domal unroofing and drainage development during early orogenic growth. Earth and Planetary Science Letters 268, 487-500.

Gattacceca, J., Deino, A., Rizzo, R., Jones, D.S., Henry, B., Beaudoin, B., Vadeboin, F., 2007. Miocene rotation of Sardinia: New paleomagnetic and geochronological constraints and geodynamic implications. Earth and Planetary Science Letters 258, 359-377.

Jackson, M.J., Banerjee, S.K., Marvin, J.A., Lu, R., Gruber, W., 1991. Detrital remanence, inclination errors, and anhysteretic remanence anisotropy: quantitative model and experimental results. Geophysical Journal International 104, 95-103.

Kirschvink, J.L., 1980. The least-squares line and plane and the analysis of paleomagnetic data. Geophysical Journal of the Royal Astronomical Society 62, 699-718.

Kodama, K, P., 2009. Simplification of the anisotropy-based inclination correction technique for magnetite- and hematite-bearing rocks: a case study from the Carboniferous Glenshaw and Mauch Chunk Formations, North America. Geophysical Journal International 176, 467-477.

Lowrie, W., 1990. Identification of ferromagnetic minerals in the rock by coercivity and unbloking temperature properties. Geophysical Research Letters 17, 159-162.

Maffione, M., Thieulot, C., van Hinsbergen, D. J. J., Morris, A., Plümper, O., Spakman, W. 2015. Dynamics of intraoceanic subduction initiation: 1 . Oceanic detachment fault inversion and the formation of supra-subduction zone ophiolites. Geochemistry, Geophysics, Geosystems 16, doi:10.1002/2015GC005746.

Malusà, M.G., Faccenna, C., Baldwin, S.L., Fitzgerald, P.G., Rossetti, F., Balestrieri, M.L., Danišík, M., Ellero, A., Ottria, G., Piromallo, C., 2015. Contrasting styles of (U) HP rock exhumation along the Cenozoic Adria-Europe plate boundary (Western Alps, Calabria, 
Corsica). Geochemistry, Geophysics, Geosystems, 16, 1786-1824.

Malusà, M. G., Anfinson, O. A., Dafov, L. N., Stockli, D. F., 2016. Tracking Adria indentation beneath the Alps by detrital zircon U-Pb geochronology: Implications for the Oligocene-Miocene dynamics of the Adriatic microplate. Geology 44/2, 155-158.

Martire, L., Clari, 1994. Evaluation of sedimentation rates in Jurassic-Cretaceous pelagic facies of the Trento Plateau: relevance of discontinuities and compaction. Giorn. Geol. 56, 193-209.

Martire, L., 1996, Stratigraphy, Facies and Synsedimentary Tectonics in the Jurassic Rosso Ammonitico Veronese (Altopiano di Asiago, NE Italy). Facies 35, 209-236.

Martire, L., Clari, P. A., Lozar, F., Pavia, G., 2006. The Rosso Ammonitico Veronese (middleupper Jurassic of the Trento Plateau): a proposal of lithostratigraphic ordering and formalization. Riv. It. Paleont. Strat. 112, 227-250.

Márton, E., Márton, P., 1981. Mesozoic paleomagnetism of the Transdanubian Central Mountains and its tectonic implications. Tectonophysics 72, 129-140.

Márton, E., Márton, P. 1983. A refined apparent polar wander curve for the Transdanubian Central Mountains and its bearing on the Mediterranean tectonic history. Tectonophysics 98, 43-57.

Márton, E., Nardi, G., 1994. Cretaceous palaeomagnetic results from Murge (Apulia, Southern Italy): tectonic implications. Geophysical Journal International 119, 842856.

Márton, E., Veljović, D. 1983. Paleomagnetism of the Istria peninsula, Yugoslavia. Tectonophysics 91, 73-87.

Márton, E., Drobne, K., Ćosović, V., Moro, A. 2003: Palaeomagnetic evidence for Tertiary counterclockwise rotation of Adria. Tectonophysics 377/1-2, 143-156.

Márton, E., Ćosović, V., Moro, A., Zvocak, S. 2008: The motion of Adria during the Late Jurassic and Cretaceous: New paleomagnetic results from stable Istria. Tectonophysics 454/1-4, 44-53.

Márton, E., Zampieri, D., Grandesso P., Ćosović, V., Moro, A. 2010: New Cretaceous paleomagnetic results from the foreland of the Southern Alps and the refined apparent polar wander path for stable Adria. Tectonophysics 480, 57-72.

Márton, E., Ćosović, V., Bucković, D., Moro, A. 2010: The tectonic development of the Northern Adriatic region constrained by Jurassic and Cretaceous paleomagnetic results. Tectonophysics 490, 93-102.

Márton, E., Zampieri, D., Kázmér, M., Dunkl, I., Frisch, W. 2011: New Paleocene-Eocene paleomagnetic results from the foreland of the Southern Alps confirm decoupling of stable Adria from the African plate. Tectonophysics 504, 89-99. 
Masetti, D., Fantoni, R., Romano, R., Sartorio, D., Trevisani, E., 2012. Tectonostratigraphic evolution of the Jurassic extensional basins of the eastern southern Alps and Adriatic foreland based on an integrated study of surface and subsurface data. AAPG Bulletin 96, 2065-2089.

McFadden, P. L., 1990. A new fold test for palaeomagnetic studies. Geophysical Journal International 103, 163-169.

McFadden, P.L., McElhinney, M. W., 1990. Classification of the reversal test in palaeomagnetism. Geophysical Journal International 103, 725-729.

Muttoni, G., Erba, E., Kent, D. V., Bachtadse, V., 2005. Mesozoic Alpine facies deposition as a result of past latitudinal plate motion. Nature 434, 59-63.

Muttoni, G., Dallanave, E., Channell, J. E. T., 2013. The drift history of Adria and Africa from $280 \mathrm{Ma}$ to Present, Jurassic true polar wander, and zonal climate control on Tethyan sedimentary facies, Palaeogeography, Palaeoclimatology, Palaeoecology 386, 415435.

Platt, J. P., Behrmann, J. H., Cunningham, P. C., Dewey, J. F., Helman, M., Parish, M., Shepley, M. G., Wallis, S., Weston, P. J., 1989. Kinematics of the Alpine arc and the motion history of Adria. Nature 337, 158-161.

Ricou, L. E., Dercourt, J., Geyssant, J., Grandjacquet, C., Lepvrier C., Biju-Duval, D., 1986. Geological constraints on the Alpine evolution of the Mediterranean Tethys. Tectonophysics 123/1-4, 83-122.

Romano, R., Barattolo, F., Masetti, D., 2005. Biostratigraphic evidence of the middle Liassic hiatus in the Foza Section. (Eastern sector of the Trento Platform, Calcari Grigi Formation, Venetian Prealps). Boll. Soc. Geol. Ital. 124, 301-312.

Rosenbaum, G., Lister, G. S., Duboz, C., 2004. The Mesozoic and Cenozoic motion of Adria (central Mediterranean): a review of constraints and limitations. Geodinamica Acta 17/2, 125-139.

Sarti, M., Bosellini, A., Winterer, E. L., 1993. Basin geometry and architecture of a Tethyan passive margin, southern Alps, Italy: Implications for rifting mechanisms, in Watkins, J.S., Zhiquiang, F., McMillan, K. (eds.), Geology and geophysics of continental margins: AAPG Memoir 53, 241-258.

Satolli, S., Besse, J., Speranza, F., Calamita, F., 2007. The 125-150 Ma high- resolution Apparent Polar wander Path for Adria from magnetostratigraphic sections in UmbriaMarche (Northern Apennines, Italy): Timing and duration of the global Jurassic Cretaceous hairpin turn. Earth and Planet Science Letter 257, 329-342.

Satolli, S., Besse, J.,Calamita, F., 2008. Paleomagnetism of Aptian-Albian Sections from the Northern Apennines (Italy): implications for the 150-100 Ma apparent polar wander of Adria and Africa. Earth and Planetary Science Letters 276, 115-128. 
Schlanger, S.O., Jenkyns, H.C., 1976. Cretaceous oceanic anoxic events: Causes and consequences. Geologie en mijnbouw 55, 179-184.

Schmid, S.M., Aebli, H.R., Heller, F., Zingg, A., 1989. The role of the Periadriatic Line in the tectonic evolution of the Alps, in Coward, M.P., et al., eds., Alpine tectonics. Geological Society of London Special Publication 45, 153-171.

Soffel, H., 1978. Reinterpretation of palaeomagnetism of the Colli Euganei and Monti Lessini (Italy). Journal of Geophysics 45, 35-39.

Speranza, F., Kissel, C., 1993. First paleomagnetism of Eocene rocks from Gargano: widespread overprint or non rotation? Geophysical Research Letters 20/23, 26272630.

Speranza, F., Minelli, L., Pignatelli, A., Chiappini, M., 2012. The Ionian Sea: The oldest in situ ocean fragment of the world? Journal of Geophysical Research , B12101.

Stephenson, A., Sadikun, S., Potter, D.K., 1986. A theoretical and experimental comparison of the anisotropies of magnetic susceptibility and remanence in rocks and minerals. Geophys. J. R. Astron. Soc. 84, 185-200.

Sturani, C., 1964. La successione delle faune ad ammoniti nelle formazioni medio-giurassiche delle Prealpi Venete occidentali. Mem. Ist. Geol. Min. Univ. Padova, 24, 1-63.

Sturani, C., 1971. Ammonites and stratigraphy of the "Posidonia alpina" beds of the Venetian Alps (Middle Jurassic, mainly Bajocian): Mem. Ist. Geol. Min. Univ. Padova, 28, 1-190.

Tomljenović, B., Csontos, L., 2001. Neogene-Quaternary structures in the border zone between Alps, Dinarides and Pannonian Basin (Hrvatsko zagorje and Karlovac Basins, Croatia). International Journal of Earth Sciences 90, 560-578.

Torsvik, T. H., Van der Voo, R., Preeden, U., Mac Niocaill, C., Steinberger, B., Doubrovine, P. V., van Hinsbergen, D. J. J., Domeier, M., Gaina, C., Tohver, E., Meert, J. G., McCausland, P. J. A., Cocks, L. R. M., 2012. Phanerozoic polar wander, paleogeography and dynamics. Earth Sci. Rev. 114, 325-368.

Tozzi, M., Kissel, C., Funiciello, R., Laj, C., Parotto, M., 1988. A clockwise rotation of Southern Apulia? Geophysical Research Letters 15, 681-684.

Ustaszewski, K., Schmid, S. M., Fügenschuh, B., Tischler, M., Kissling, E., Spakman, W., 2008. A map-view restoration of the Alpine-Carpathian-Dinaric system for the Early Miocene. Swiss Journal of Geosciences 101, 273-294.

VandenBerg, J., 1983. Reapprisal of paleomagnetic data from Gargano (South Italy). Tectonophysics 98, 29-41.

VandenBerg, J., Wonders, A.A.H., 1980. Palaeomagnetism of Late Mesozoic pelagic limestones from the Southern Alps. Journal of Geophysical Research 85, 3623-3627. 
van Hinsbergen, D.J.J., Mensink, M., Langereis, C.G., Maffione, M., Salluto, L., Tropeano, M., Sabato, L., 2014. Did Adria rotate relative to Africa? Solid Earth 5, 611-629.

Westphal, M., Bazhenov, M. L., Lauer, J. P., Pechersky, D. M., Sibuet, J.-C., 1986. Paleomagnetic implications on the evolution of the Tethys belt from the Atlantic Ocean to the Pamirs since the Triassic. Tectonophysics 123/1-4, 37-82.

Winterer, E.L., Bosellini, A., 1981. Subsidence and Sedimentation on a Jurassic Passive Continental Margin, Southern Alps, Italy. AAPG Bull. 65, 394-421.

Woodfine, R. G., Jenkyns, H. C., Sarti, M., Baroncini, F., Violante, C., 2008. The response of two Tethyan carbonate platforms to the early Toarcian (Jurassic) oceanic anoxic event: environmental change and differential subsidence. Sedimentology 55, 10111028.

Wortman, U. G., Weissert, H., Funk, H., Hauck, J., 2001. Alpine plate kinematics revisited: The Adria Problem. Tectonics, 20 (1), 134-147.

Zampieri, D., 2000. Segmentation and linkage of the Lessini Mountains normal faults, Southern Alps, Italy. Tectonophysics 319, 19-31.

Zampieri, D., Massironi, M., 2007. Evolution of a poly-deformed relay zone between fault segments in the eastern Southern Alps, Italy. In: Cunningham, D., Mann, P. (eds), Tectonics of Strike-slip Restraining and Releasing Bends, Geol. Soc., London, Special Publication, 290, 351-366.

Zempolich,W. G., 1993. The drowning succession in Jurassic carbonates of the Venetia Alps, Italy: A record of supercontinent breakup, gradual eustatic rise, and eutrophication of shallow-water environments, in R. G. Louks and J. F. Sarg, eds., Carbonate sequence stratigraphy: Recent developments and applications: AAPG Memoir 57, 63-105. 
Table 1

\begin{tabular}{|c|c|c|c|c|c|c|c|c|c|c|c|c|c|c|c|c|c|}
\hline & Locality & $\begin{array}{l}\text { Lat. } \mathrm{N}^{\circ} \\
\text { Long. } \mathrm{E}^{\circ}\end{array}$ & n/no & $\mathbf{D}^{\circ}$ & 10 & k & $\alpha_{95}^{\circ}$ & $\mathrm{D}_{\mathrm{c}^{\circ}}$ & $\mathrm{I}_{\mathrm{C}}{ }^{\circ}$ & k & $\alpha_{95}^{\circ}$ & dip & polarity & $\begin{array}{l}\text { Pole } \\
\text { Lat. }\end{array}$ & $\begin{array}{l}\text { Pole } \\
\text { Long. }\end{array}$ & $\delta m$ & $\delta p$ \\
\hline 1 & $\begin{array}{l}\text { Arzere II } \\
\text { SA 1117-125 }\end{array}$ & $\begin{array}{l}45^{\circ} 35^{\prime} 12^{\prime \prime} \\
11^{\circ} 00^{\prime} 36^{\prime \prime}\end{array}$ & $5 / 9$ & 131.3 & -27.2 & 32.9 & 13.5 & 126.0 & -29.6 & 32.9 & 13.5 & $204 / 9$ & $\begin{array}{l}\operatorname{mix} . \\
\text { Roi }\end{array}$ & 36.2 & 265.7 & 14.9 & 8.3 \\
\hline 2 & $\begin{array}{l}\text { Cima di Mezzo } \\
\text { SA 1193-204 }\end{array}$ & $\begin{array}{l}45^{\circ} 40^{\prime} 54^{\prime \prime} \\
11^{\circ} 03^{\prime} 14^{\prime \prime}\end{array}$ & $11 / 12$ & 297.1 & +24.3 & 78.1 & 5.2 & 296.0 & +35.1 & 78.1 & 5.2 & $127 / 11$ & $\begin{array}{l}\operatorname{mix} . \\
\text { Rci }\end{array}$ & 31.8 & 276.7 & 6.0 & 3.5 \\
\hline 3 & $\begin{array}{l}\text { Val di Porro } \\
\text { SA1251-259 }\end{array}$ & $\begin{array}{l}45^{\circ} 37^{\prime} 38^{\prime \prime} \\
11^{\circ} 02^{\prime} 52^{\prime \prime}\end{array}$ & $9 / 9$ & 301.3 & +34.1 & 66.7 & 6.3 & 298.8 & +27.2 & 67.7 & 6.3 & $268 / 8$ & $\begin{array}{l}\operatorname{mix} . \\
\mathrm{Rb}\end{array}$ & 30.3 & 270.4 & 6.9 & 3.7 \\
\hline 4 & $\begin{array}{l}\text { Campofontana } \\
\text { SA 1156-164 }\end{array}$ & $\begin{array}{l}45^{\circ} 38^{\prime} 29^{\prime \prime} \\
11^{\circ} 09^{\prime} 02^{\prime \prime}\end{array}$ & $5 / 9$ & 117.2 & -31.8 & 72.1 & 9.1 & 121.3 & -26.7 & 72.1 & 9.1 & $355 / 9$ & $\begin{array}{l}\operatorname{mix} . \\
\mathrm{Rb}\end{array}$ & 31.8 & 268.3 & 9.9 & 5.4 \\
\hline 5 & $\begin{array}{l}\text { Arzere III } \\
\text { SA 1126-134 }\end{array}$ & $\begin{array}{l}45^{\circ} 39^{\prime} 38^{\prime \prime} \\
10^{\circ} 57^{\prime} 46^{\prime \prime}\end{array}$ & $8 / 9$ & 340.1 & +39.2 & 47.6 & 8.1 & 330.4 & +38.8 & 47.6 & 8.1 & $247 / 12$ & $\mathrm{~N}$ & 56.2 & 246.5 & 9.6 & 5.7 \\
\hline 6 & $\begin{array}{l}\text { Montarina II } \\
\text { SA 1266-279 }\end{array}$ & $\begin{array}{l}45^{\circ} 34^{\prime} 53^{\prime \prime} \\
11^{\circ} 02^{\prime} 09^{\prime \prime}\end{array}$ & $9 / 14$ & 325.6 & +47.2 & 368.3 & 2.7 & 319.6 & +46.2 & 368.3 & 2.7 & $242 / 6$ & $\mathrm{~N}$ & 53.4 & 265.6 & 3.5 & 2.2 \\
\hline 7 & $\begin{array}{l}\text { Vallene } \\
\text { SA 1280-297 } \\
\text { SA 1280-285 } \\
\text { SA 1286-291 } \\
\text { SA 1292-297 }\end{array}$ & $\begin{array}{l}45^{\circ} 39^{\prime} 38^{\prime \prime} \\
10^{\circ} 57^{\prime} 45^{\prime \prime}\end{array}$ & $\begin{array}{l}5 / 6 \\
3 / 6 \\
6 / 6\end{array}$ & $\begin{array}{l}123.1 \\
148.0 \\
308.5\end{array}$ & $\begin{array}{l}-45.1 \\
-62.8 \\
+13.9\end{array}$ & $\begin{array}{r}45.9 \\
63 \\
244\end{array}$ & $\begin{array}{r}11.4 \\
16 \\
4\end{array}$ & $\begin{array}{l}123.1 \\
164.5 \\
308.0\end{array}$ & $\begin{array}{r}-45.1 \\
-69.8 \\
-4.4\end{array}$ & 45.9 & 11.4 & $\begin{array}{c}\text { horizon. } \\
110 / 10 \\
110 / 10\end{array}$ & & & & & \\
\hline 8 & $\begin{array}{l}\text { Fosse } \\
\text { SA1310-319 }\end{array}$ & $\begin{array}{l}45^{\circ} 38^{\prime} 30^{\prime \prime} \\
10^{\circ} 56^{\prime} 42^{\prime \prime}\end{array}$ & $10 / 10$ & 160.2 & -52.3 & 183.9 & 3.6 & 147.2 & -49.2 & 183.9 & 3.6 & $260 / 11$ & $\mathrm{R}$ & 60.1 & 261.1 & 4.8 & 3.2 \\
\hline 9 & $\begin{array}{l}\text { Due Cerri (Lugo) } \\
\text { SA } 1136-155\end{array}$ & & & & & & & & & & & & & & & & \\
\hline & SA $1136-143$ pink & $\begin{array}{l}45^{\circ} 33^{\prime} 49^{\prime \prime} \\
11^{\circ} 00^{\prime} 50^{\prime \prime}\end{array}$ & $7 / 8$ & 326.3 & +41.6 & 81.0 & 6.7 & 320.6 & +39.4 & 81.0 & 6.7 & $252 / 7$ & $\mathrm{~N}$ & 50.5 & 258.4 & 8.0 & 4.8 \\
\hline & SA $1144-155$ white & $\begin{array}{l}45^{\circ} 33^{\prime} 49^{\prime \prime} \\
11^{\circ} 00^{\prime} 50^{\prime \prime}\end{array}$ & $8 / 12$ & 327.4 & +45.2 & 50.3 & 7.9 & 320.9 & +43.0 & 50.3 & 7.9 & $252 / 7$ & $\mathrm{~N}$ & 52.6 & 261.2 & 9.8 & 6.1 \\
\hline 10 & $\begin{array}{l}\text { Bocca di Selva } \\
\text { SA 1205-214 }\end{array}$ & $\begin{array}{l}45^{\circ} 40^{\prime} 41^{\prime \prime} \\
11^{\circ} 03^{\prime} 05^{\prime \prime}\end{array}$ & $5 / 10$ & 320.4 & +42.8 & 145.3 & 6.4 & 322.9 & +47.2 & 145.3 & 6.4 & $112 / 5$ & $\mathrm{~N}$ & 56.1 & 263.3 & 8.3 & 5.4 \\
\hline 11 & $\begin{array}{l}\text { Montarina I } \\
\text { SA 1260-265 }\end{array}$ & $\begin{array}{l}45^{\circ} 34^{\prime} 54^{\prime \prime} \\
11^{\circ} 02^{\prime} 08^{\prime \prime}\end{array}$ & $6 / 6$ & 143.3 & -45.8 & 51.6 & 9.4 & 137.2 & -46.7 & 51.6 & 9.4 & $222 / 6$ & $\begin{array}{l}\operatorname{mix} . \\
\text { Rci }\end{array}$ & 52.0 & 268.4 & 12.1 & 7.8 \\
\hline 12 & $\begin{array}{l}\text { Tracchi } \\
\text { SA 1215-224 }\end{array}$ & $\begin{array}{l}45^{\circ} 40^{\prime} 18^{\prime \prime} \\
11^{\circ} 03^{\prime} 14^{\prime \prime}\end{array}$ & $9 / 10$ & 141.4 & -21.9 & 27.3 & 10.0 & 141.4 & -26.9 & 27.3 & 10.0 & $142 / 5$ & $\mathrm{R}$ & 44.9 & 249.6 & 10.9 & 5.9 \\
\hline 13 & $\begin{array}{l}\text { Ronconi } \\
\text { SA 1298-309 }\end{array}$ & $\begin{array}{l}45^{\circ} 38^{\prime} 13^{\prime \prime} \\
10^{\circ} 57^{\prime} 26^{\prime \prime}\end{array}$ & $8 / 12$ & 328.5 & +39.2 & 16.8 & 13.9 & 328.5 & +39.2 & 16.8 & 13.9 & horizon. & $\mathrm{N}$ & 55.3 & 249.1 & 16.6 & 9.9 \\
\hline 14 & $\begin{array}{l}\text { Bosco Chiesanova } \\
\text { SA } 1239-250\end{array}$ & $\begin{array}{l}45^{\circ} 37^{\prime} 35^{\prime \prime} \\
11^{\circ} 02^{\prime} 03^{\prime \prime}\end{array}$ & $0 / 12$ & & & & too $n$ & weak & & & & $222 / 6$ & & & & & \\
\hline 15 & $\begin{array}{l}\text { Bellori } \\
\text { SA 1225-238 }\end{array}$ & $\begin{array}{l}45^{\circ} 35^{\prime} 46^{\prime \prime} \\
10^{\circ} 59^{\prime} 48^{\prime \prime}\end{array}$ & $5 / 14$ & 147.7 & -44.3 & 55.1 & 10.4 & 131.1 & -53.1 & 55.1 & 10.4 & $190 / 14$ & $\mathrm{R}$ & 51.9 & 280.0 & 14.4 & 10.0 \\
\hline
\end{tabular}

Table 1. Summary of the new locality mean paleomagnetic directions for the Foreland of the Southern Alps (Adige embayment) based on the results of principal component analysis (Kirschvink 1980). Localities numbered according to Fig. 2.

Key: Lat.N, Lon.E: Geographic coordinates (WGS84) measured by GPS, n/no: number of used/collected samples (the samples are independently oriented cores, the rejected samples from the localities 1-11 are unstable on demagnetization, those from localities $12-15$ have extremely weak $\mathrm{NRM}) ; \mathrm{D}^{\circ}, \mathrm{I}^{\circ}\left(\mathrm{D}_{\mathrm{C}}{ }^{\circ}, \mathrm{I}_{\mathrm{C}}{ }^{\circ}\right)$ : declination, inclination before (after) tilt correction; $\mathrm{k}$ and $\alpha_{95}$ : statistical parameters (Fisher 1953); Lat., Lon.: latitude and longitude of the palaeomagnetic pole; $\delta \mathrm{m}, \delta \mathrm{p}$ : statistical parameters of the palaeomagnetic pole. Locality mean paleomagnetic results with mixed polarities are tabulated either as normal (localities 2 and 3) or reversed (localities 1,4 and 11), depending on the dominance of the samples with the respective polarity. The NRM of the samples rejected for unstable behaviour could have been composed of normal and reversed polarity components, but the two could not be separated. 
்ֻ

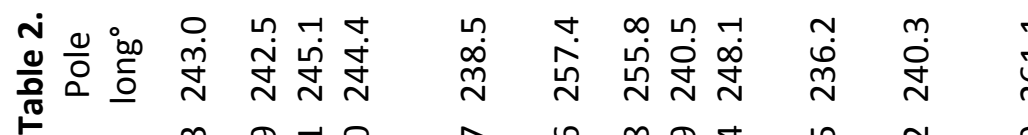

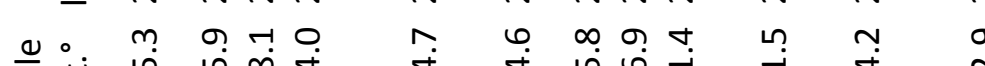

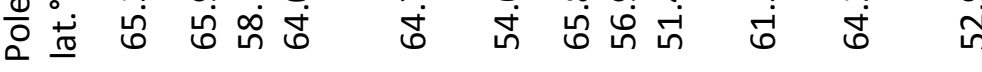

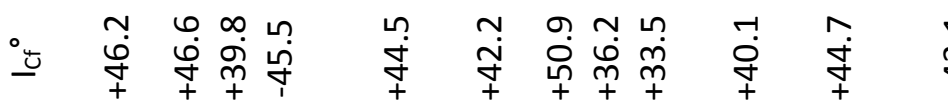

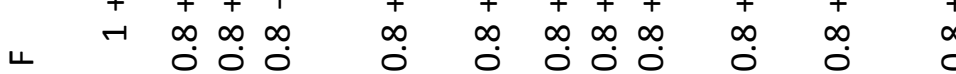

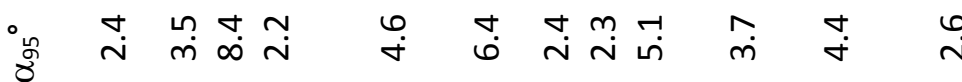

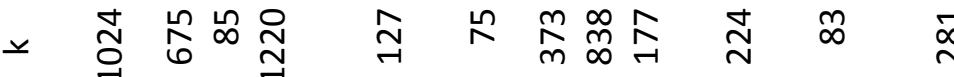

ำก

-

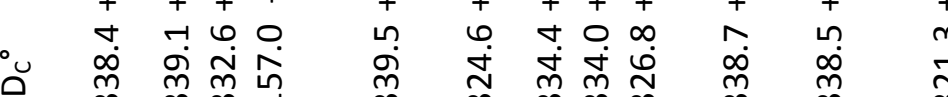

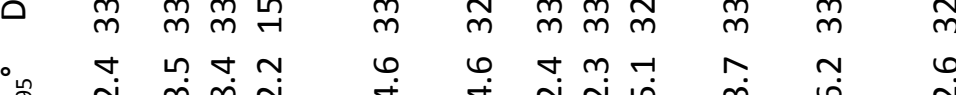

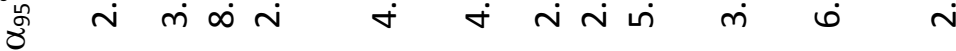

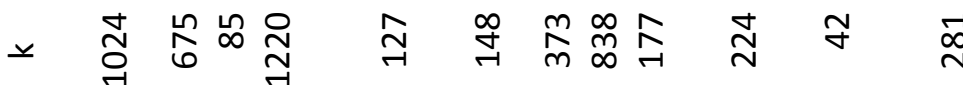

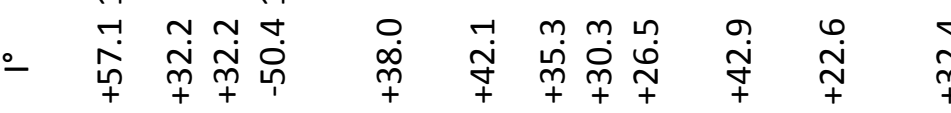

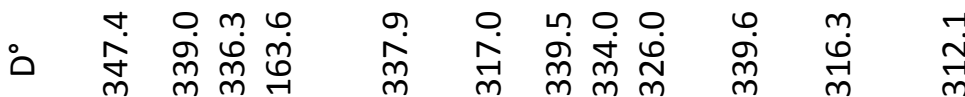

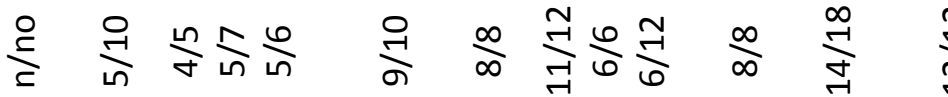

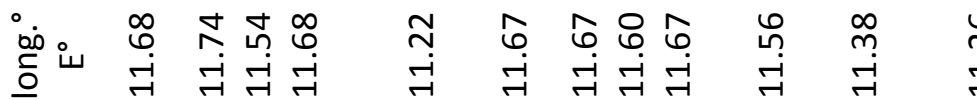

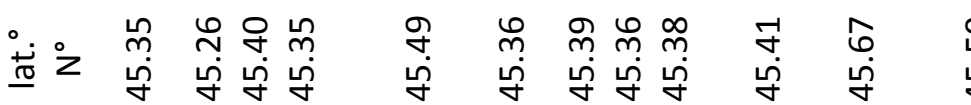

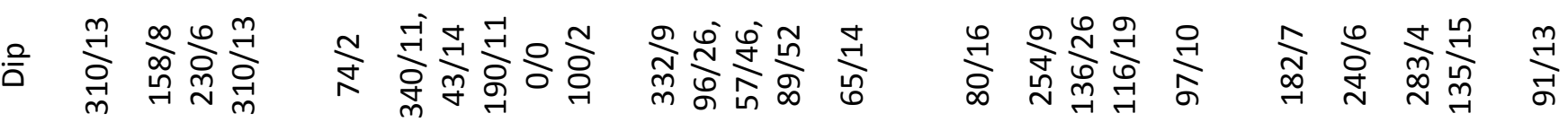

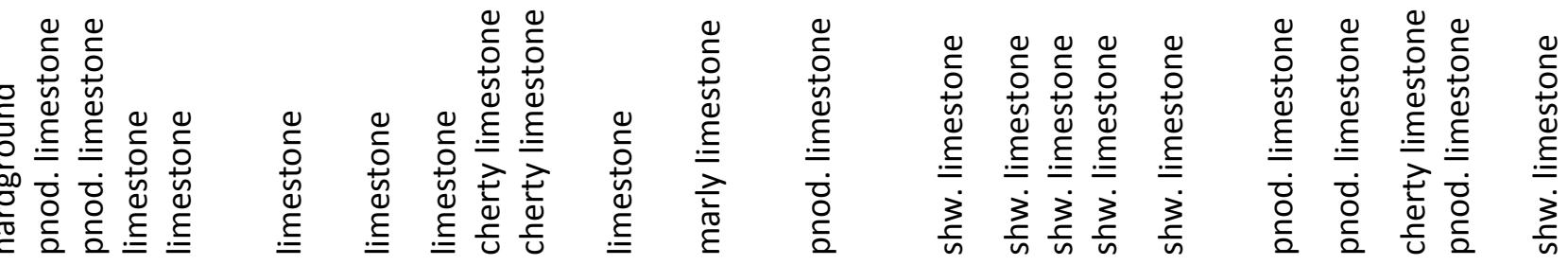

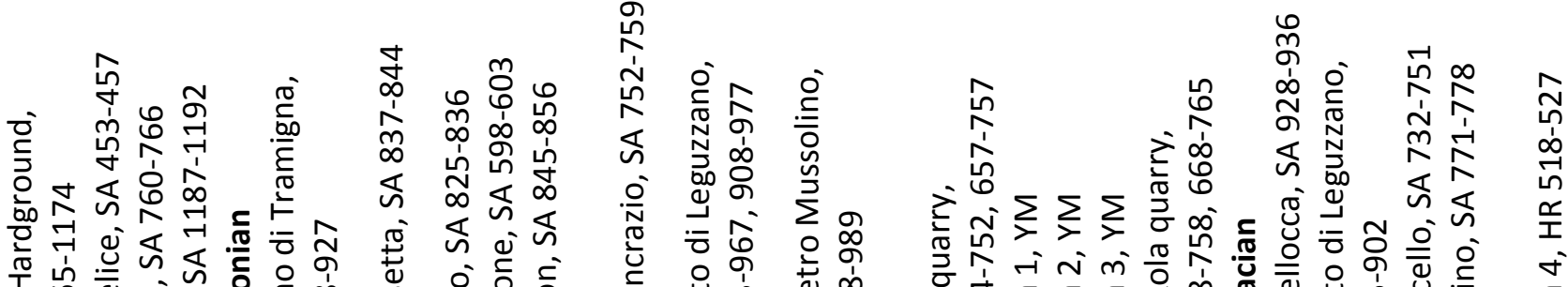

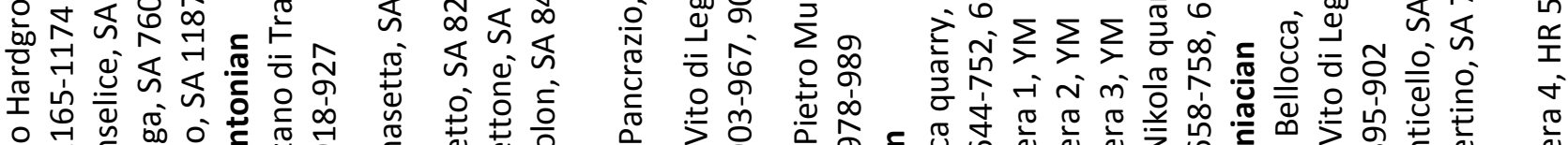

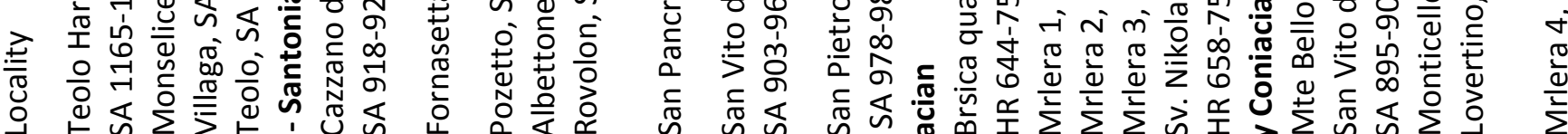

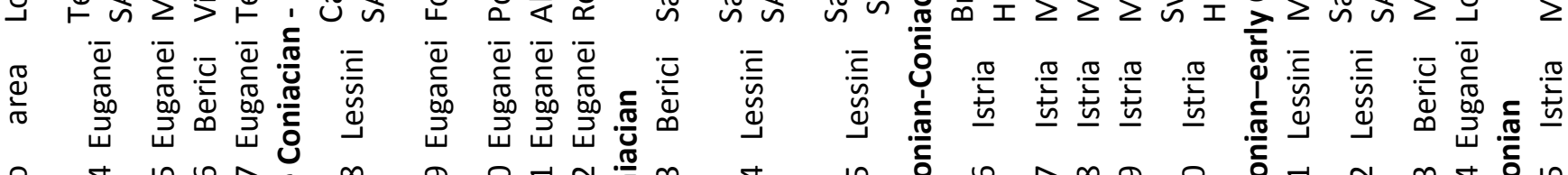

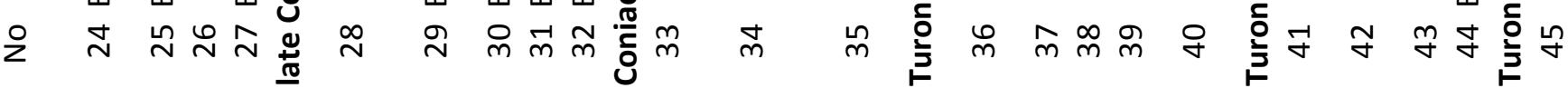


뜸

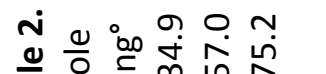

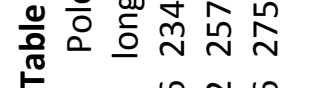

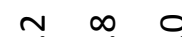

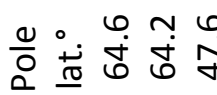

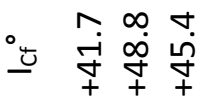

レ

$\rightarrow H r$

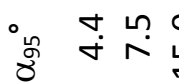

ด

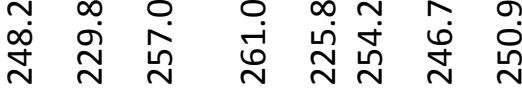

ஸे

๑ $\rightarrow$ ก $m$ ก ก ก $\infty$

ก $\stackrel{ก}{\sim}$

กั่

(n)

$m \quad \forall+\forall$

$m m m$ ஸ่ $\infty$ ஸे

i

ตं नं

ก) ต

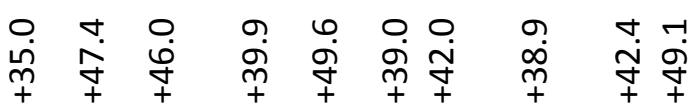

$\sim \sim m \sim n$ ต่

$\because$ न 6 .

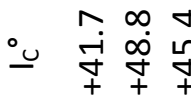
ㄷ $\infty$

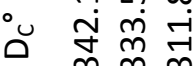

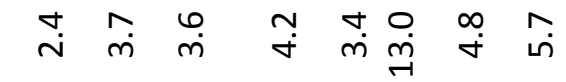

ஸे

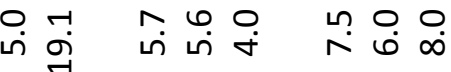

v

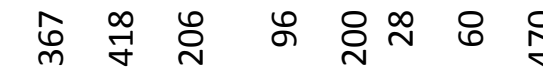

$m \underset{N}{N} \stackrel{m}{N}$

品

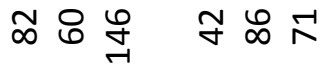

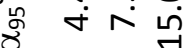

ำ

ๆ

ช.

ナ.

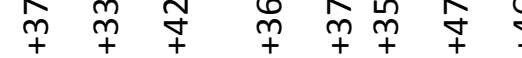

ஜ่

$\stackrel{+}{+} \stackrel{+}{+}$

$\stackrel{\infty}{m} \underset{+}{\sim}$

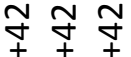

क)

r m 00

‥

$\sim \wedge 6$

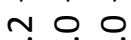

$\stackrel{m}{m} \underset{m}{m} \stackrel{\sim}{m} \stackrel{\sim}{m} m \stackrel{m}{m}$

ల్లై

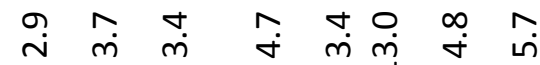

ก.

$\circ-$

ข

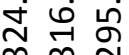

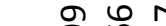

过 文尔

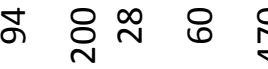

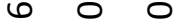

में

ก. 0 ก 0.

$\checkmark$ \%

- ஸि ச

m !?

e +0

ค

.

$+++$

$+\stackrel{+}{+}$

m

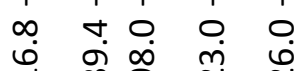

- $\quad \stackrel{m}{m} \stackrel{m}{m}$

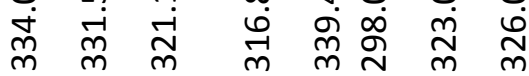

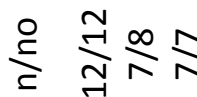

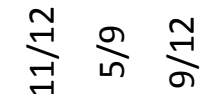

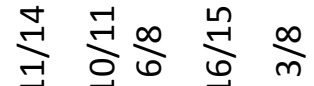

$\begin{array}{lllll}m & 0 & 0 & 0 & \\ m & 0 & 0 & N & \\ + & + & + & N & \\ + & + & + & + & \\ m & m & 0 & 0 & \end{array}$

ஸे

m $m$ m $m$ m

8

का

10

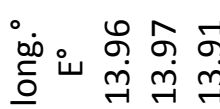

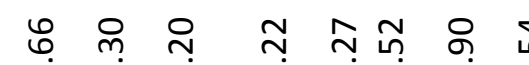

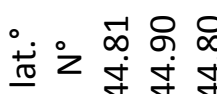

न न न न

\section{के}

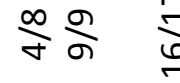

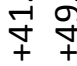

ㄴ) $N$

규

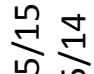

우

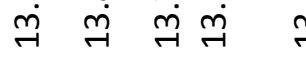

$\stackrel{\infty}{\infty}$

$\stackrel{m}{\rightarrow} \underset{\sim}{m}$

$\infty 6 \mathrm{~g}$

$\tilde{m}$ F $g$

의

난

6. 60 6 00

ம.

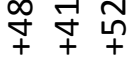

(n)

ํำ

กิ

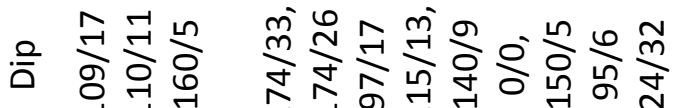

年

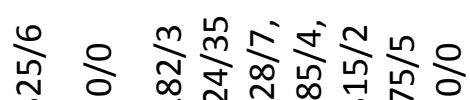

N

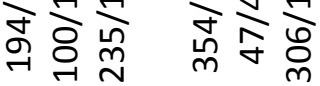

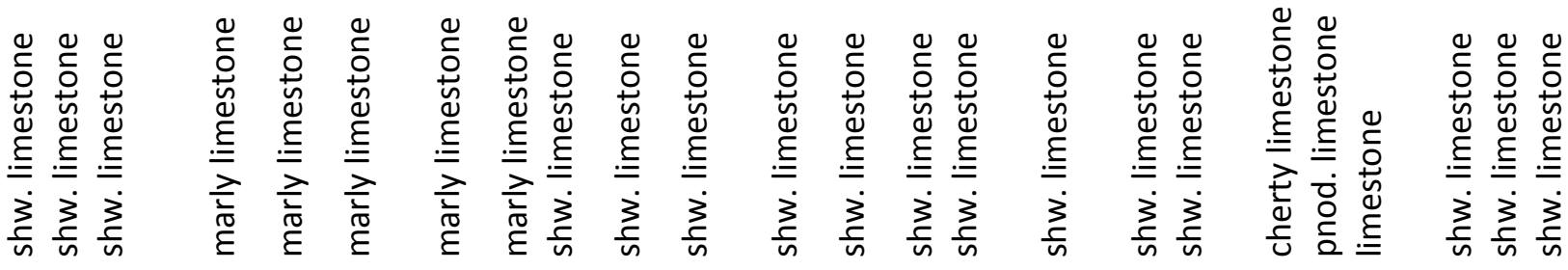

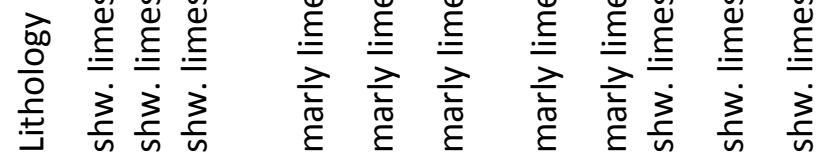

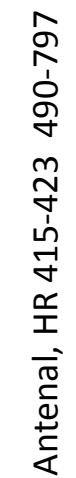

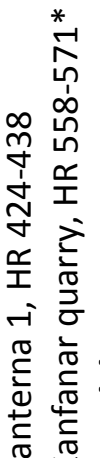

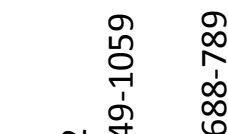

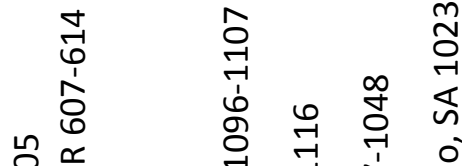

온 咭

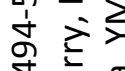

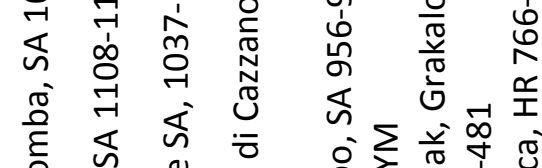

$>$ I

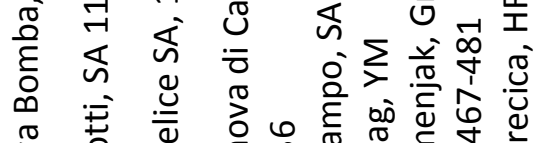

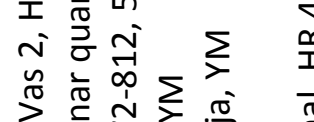

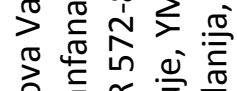

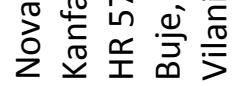

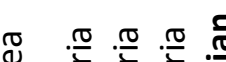

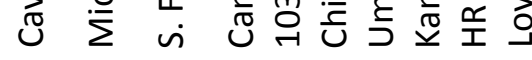

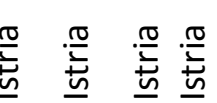

总

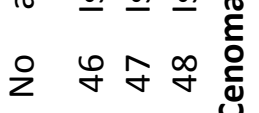

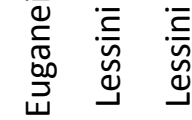

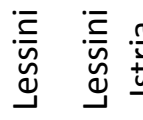

$\left.\operatorname{lin}^{2}\right)^{\circ}$

क्ष

in

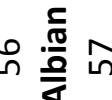

๓̊ㅇำ

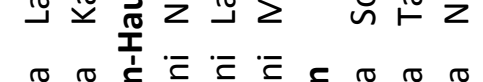

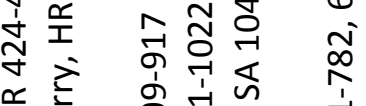

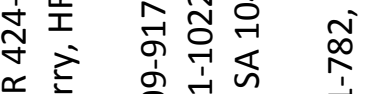

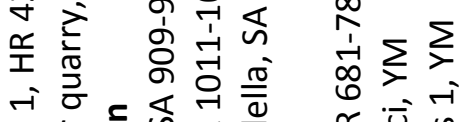

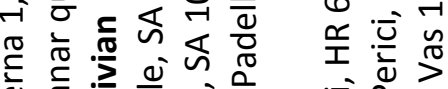

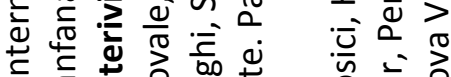

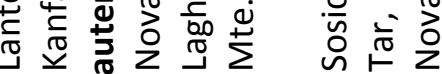

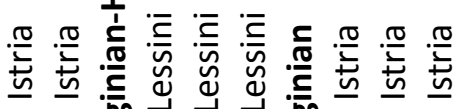
ชู 


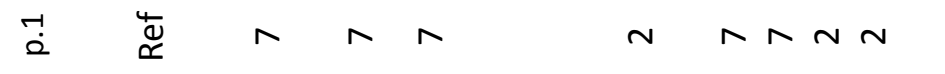

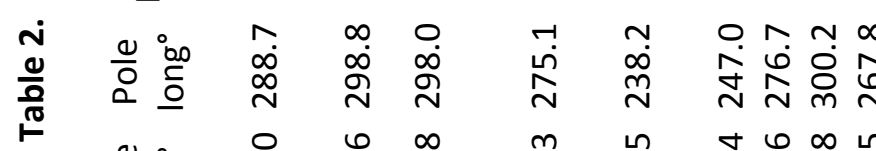

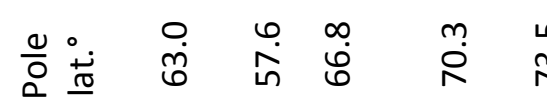

它㝊茫岁
이

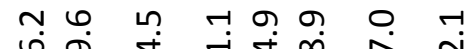
ஸ்

r.

$\circ \circ \infty$

ம்

ํ்

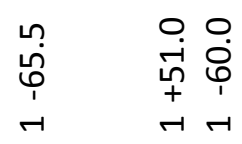

$\sim n$

กิ

$\stackrel{\infty}{\infty} \stackrel{\infty}{\circ} \stackrel{\infty}{\circ}$

$\infty \uparrow \quad 9$

。

붕

省 ஓे

$\stackrel{\sim}{\sim} \stackrel{\sim}{\rightarrow}$ กี

이 m $9 m$

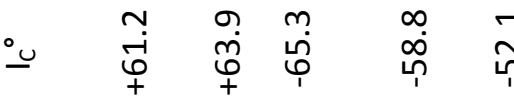

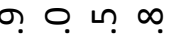
+

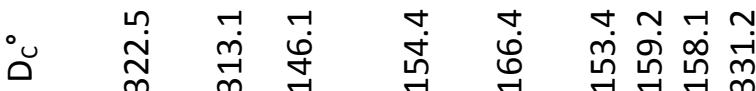

- $\quad r$ r $r$ o n

○

$\dot{\varphi} \ddot{m} \infty \stackrel{\infty}{m}$

- 华

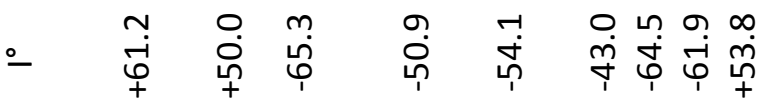

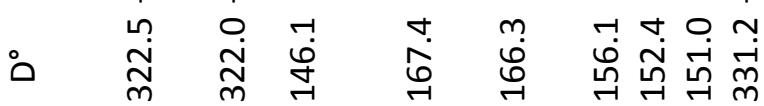

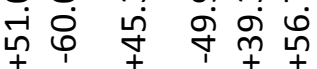

$+\infty$ n $6 \wedge m$ o

守 守

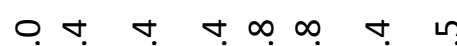

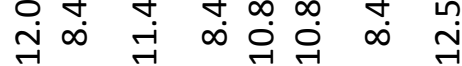

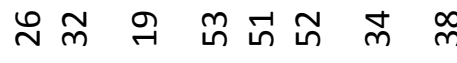

얼

$\checkmark \circ \quad m \quad 0 \quad \infty \quad m \quad r$

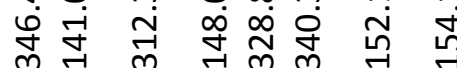

$\frac{\infty}{\kappa} \frac{\infty}{\infty} \stackrel{m}{\stackrel{0}{0}} \stackrel{0}{0}$

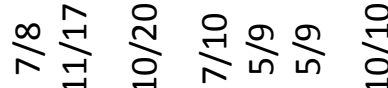

$\frac{\infty}{\operatorname{Ln}}$

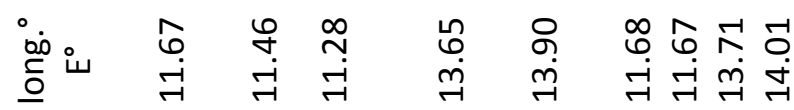

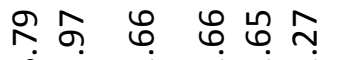

mં

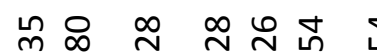

芦藏余

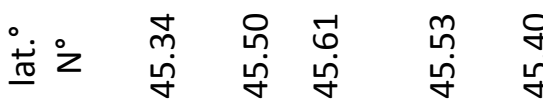

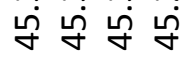

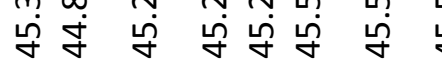

กิ

ت

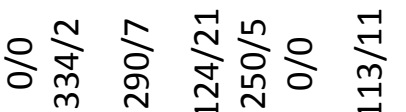

$\stackrel{\infty}{\text { ֻे }}$

우

สี $\stackrel{n}{\sim}$

ชี ส

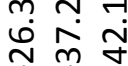

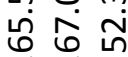

$\circ \sigma \sigma$

$\infty \dot{0} \dot{0}$

$N \infty$

å

๗்

$+6 \mathrm{~m}$

ச் ச்

ঢ 바

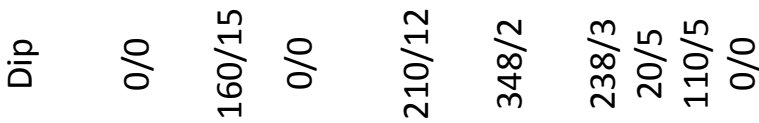

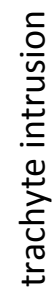

임

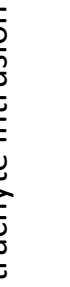

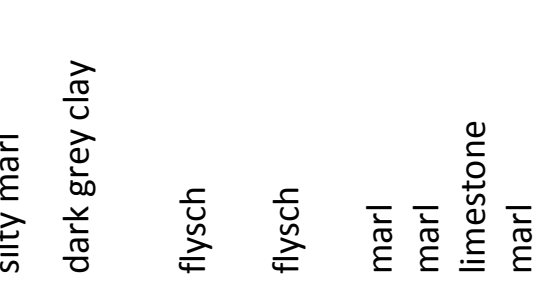

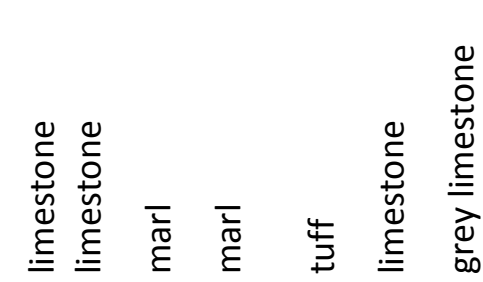

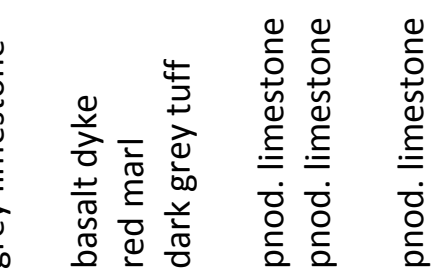

$\stackrel{\sim}{\infty}$

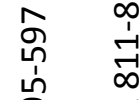

岗 文

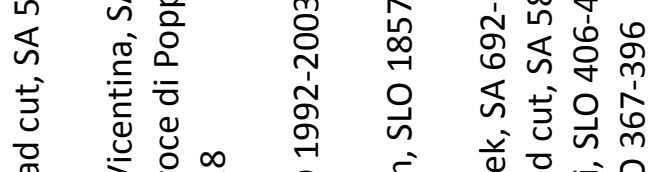

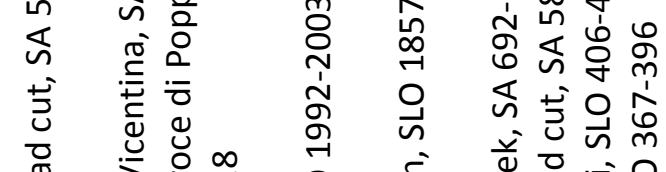

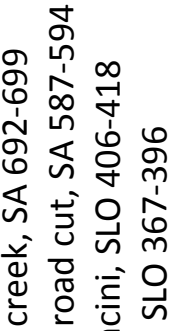

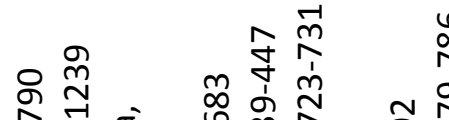

$\underset{\substack{1 \\ \infty}}{\infty}$

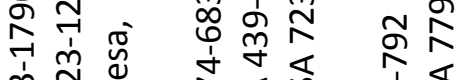

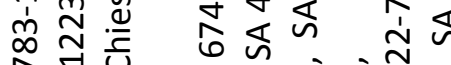

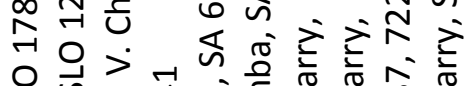

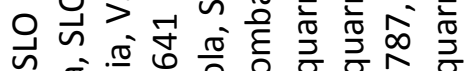

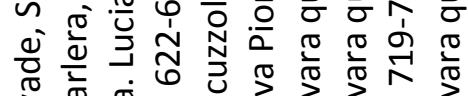

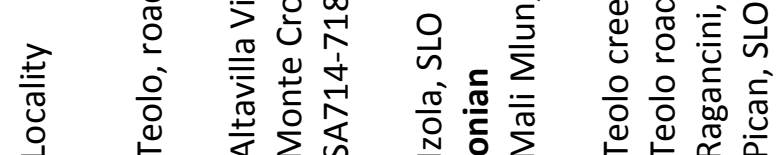

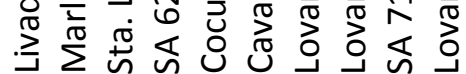

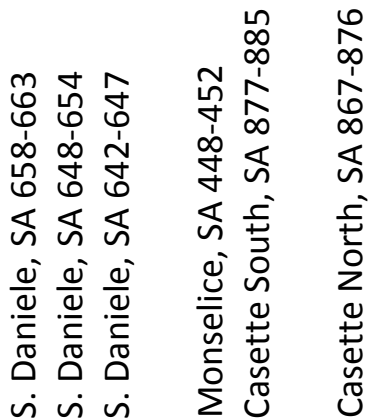

『̋

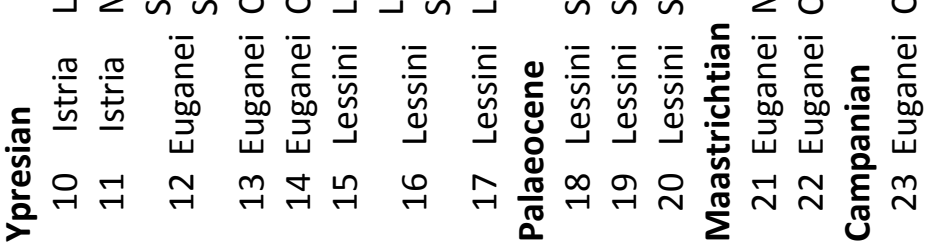




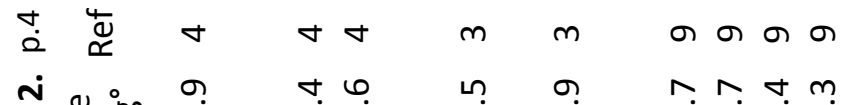

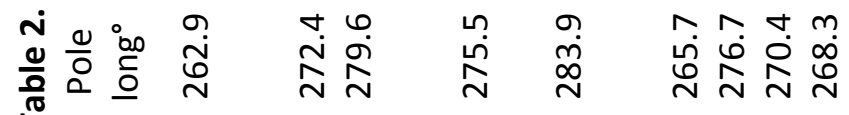

ป.

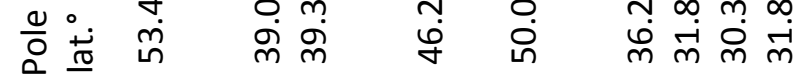

$\stackrel{\circ}{\underline{4}}$

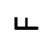

3.

ชి

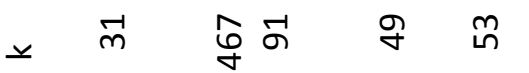

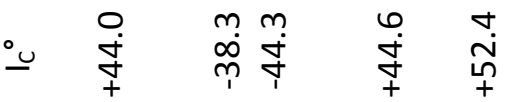

-

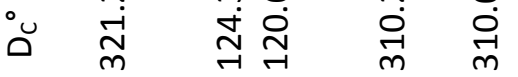

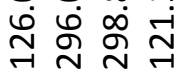

另

$\infty-1$

$\stackrel{\circ}{\circ} \stackrel{-}{\sim}$

เก $\sim m-$

mi

$\stackrel{\sim}{\sim}$

ஸे नี જ

$m \infty \hat{n} \approx$

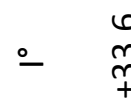

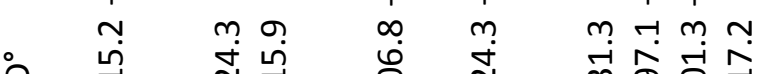

-

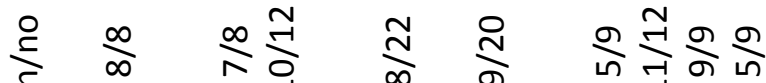

$\stackrel{\circ}{\circ} \stackrel{0}{0}$

극

ด

$\stackrel{m}{7}$

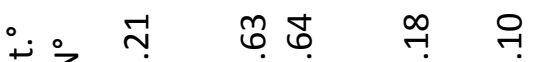

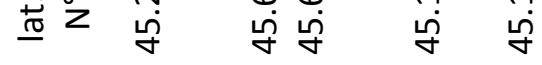

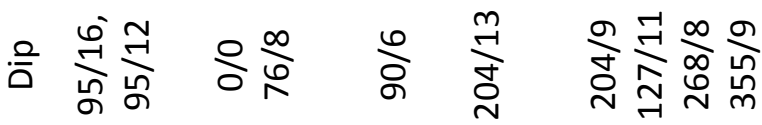

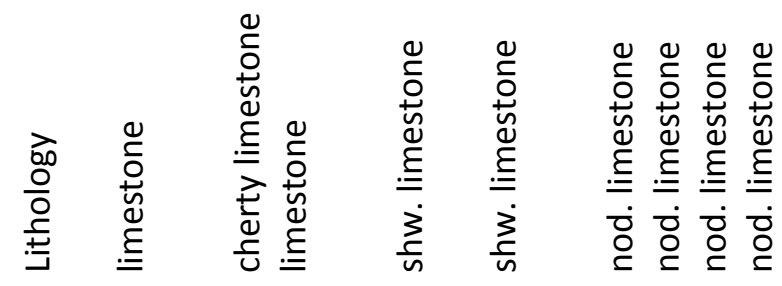

号 总

仓ิ

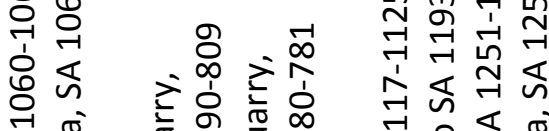

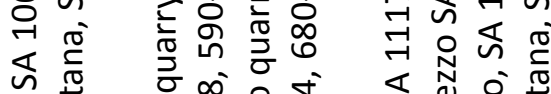

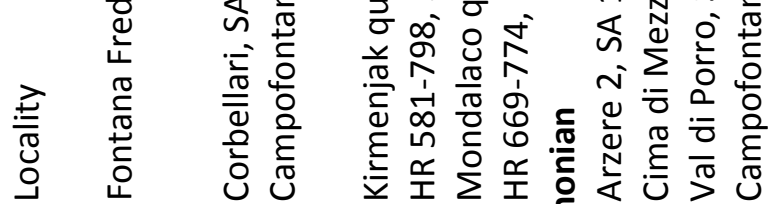

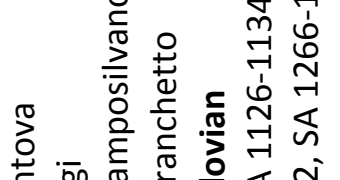

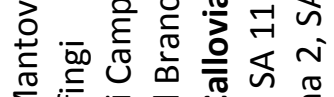

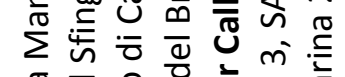
它 ठㅇ

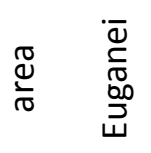

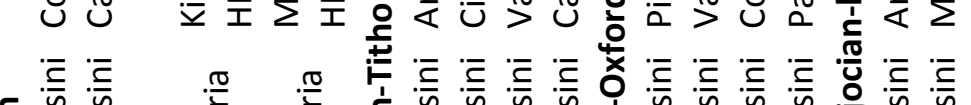

岂 N N N N N N N N N

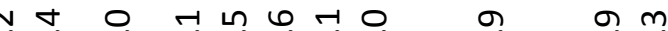

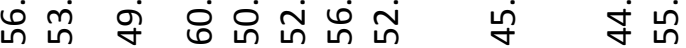

กิ

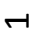

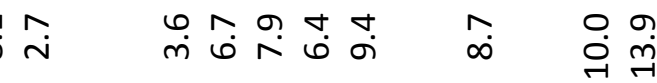
$\stackrel{\infty}{\infty} \underset{m}{\infty} \stackrel{\infty}{\rightarrow}$

$\infty \sim \pi)$ n $\infty$ ก 

ナ.

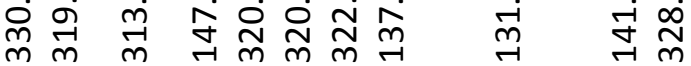

$\because \hat{n}$ ம 亦

ก 0 .

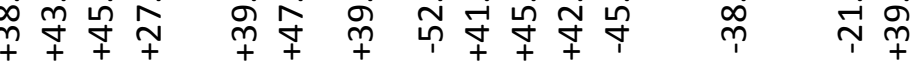

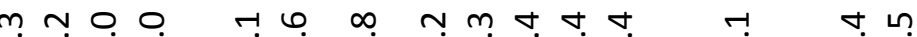
穴

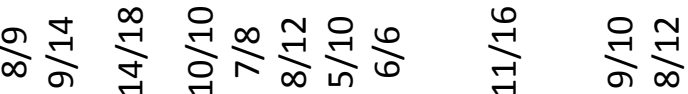

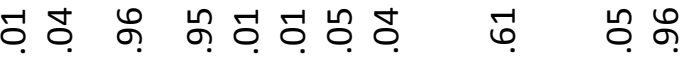

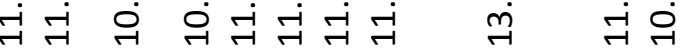

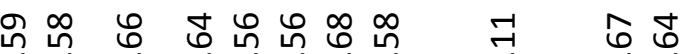

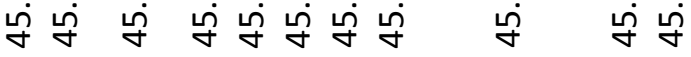

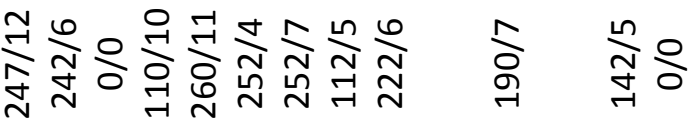

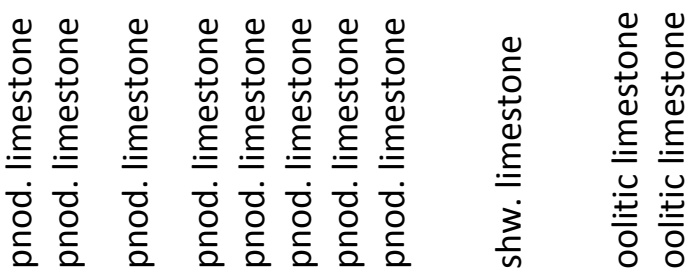

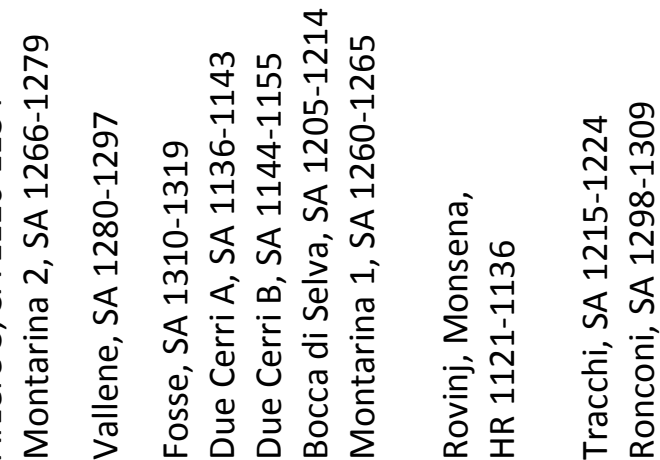

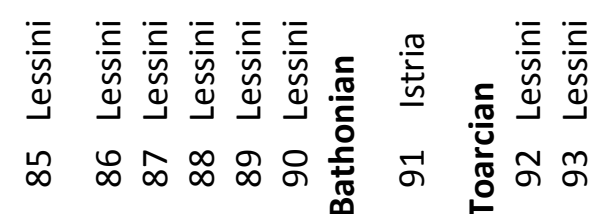




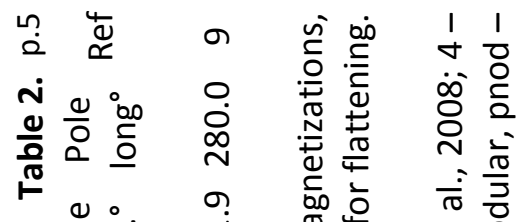

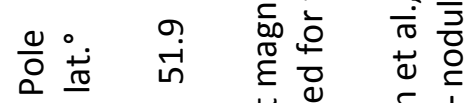
○)

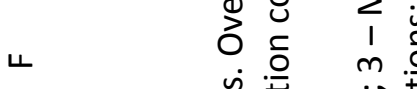
。

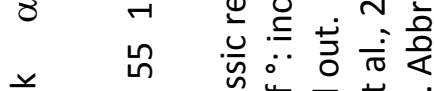
(⿹弋丁)

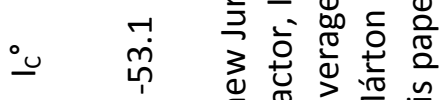
幽

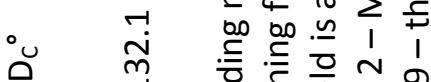

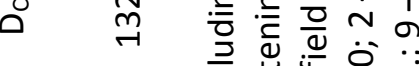

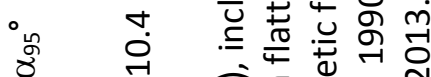

织

$\therefore$ ก

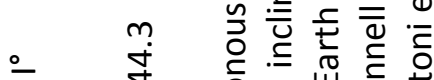

- $\quad$ व

․

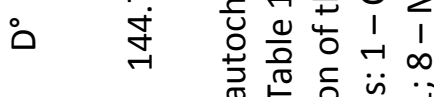

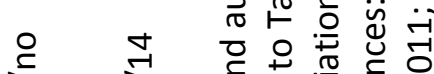

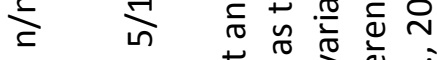

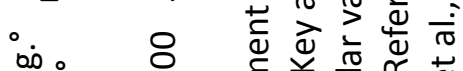

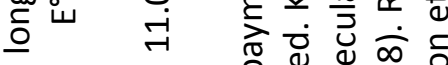

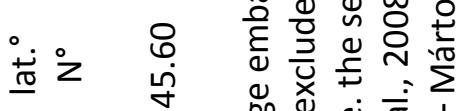

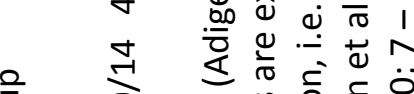

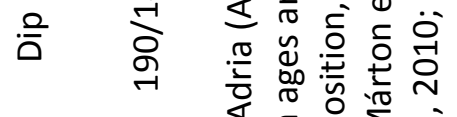

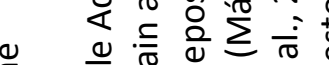
$\frac{0}{0}$

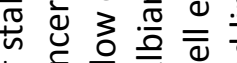

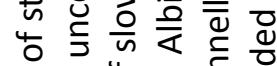

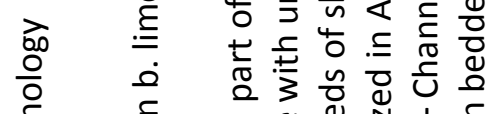

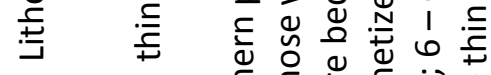

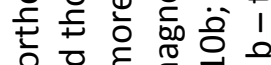
ᄃ $\frac{c}{\sigma}$ व

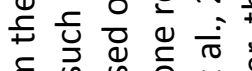

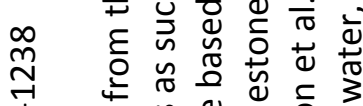

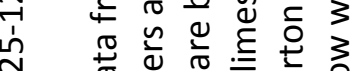

嵌

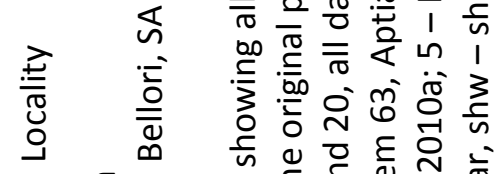

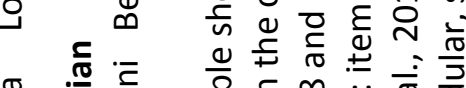

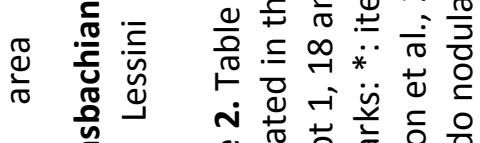

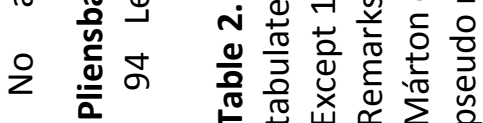




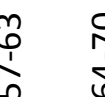

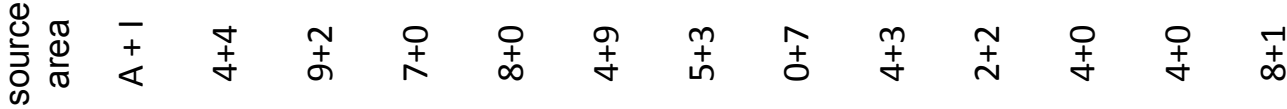

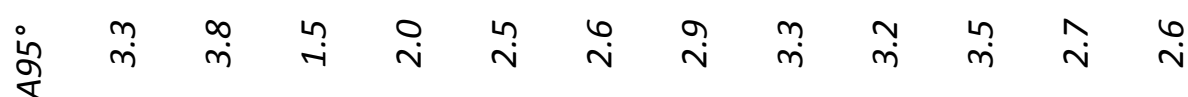

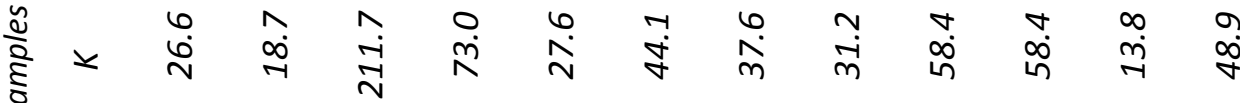

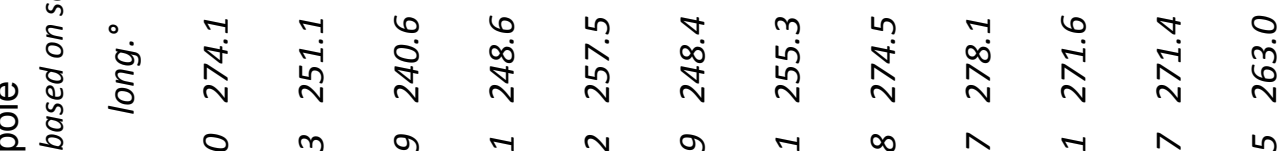

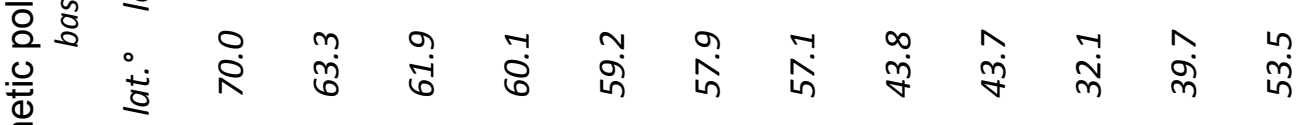

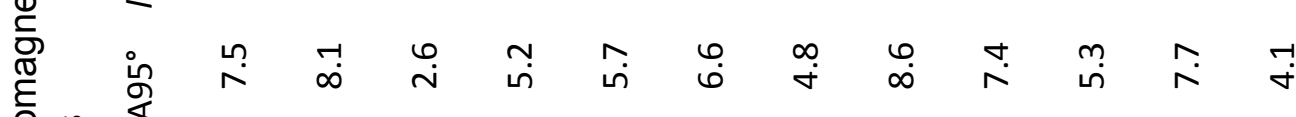

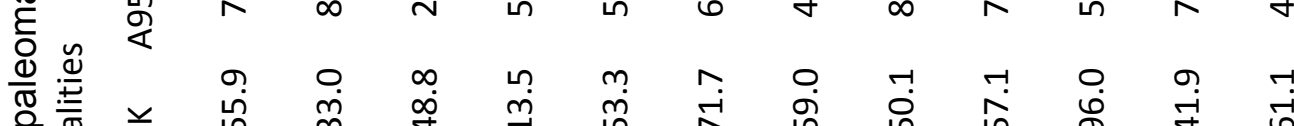

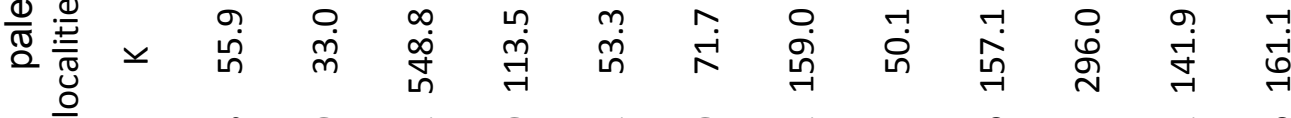

ठ

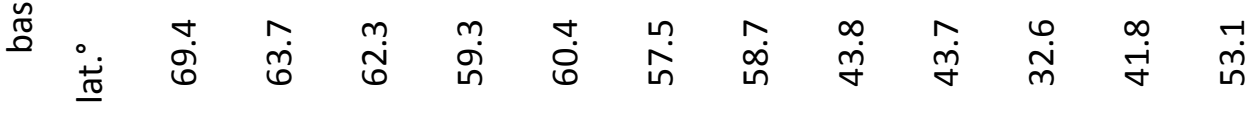

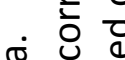

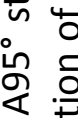

¿.

음

in

ชั

高

은

응

完

Q ¿े

范竞

प응 등

忞

ำ

ㄷํㅇ 잉

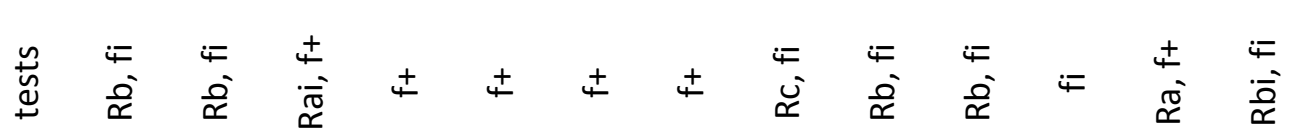

흐

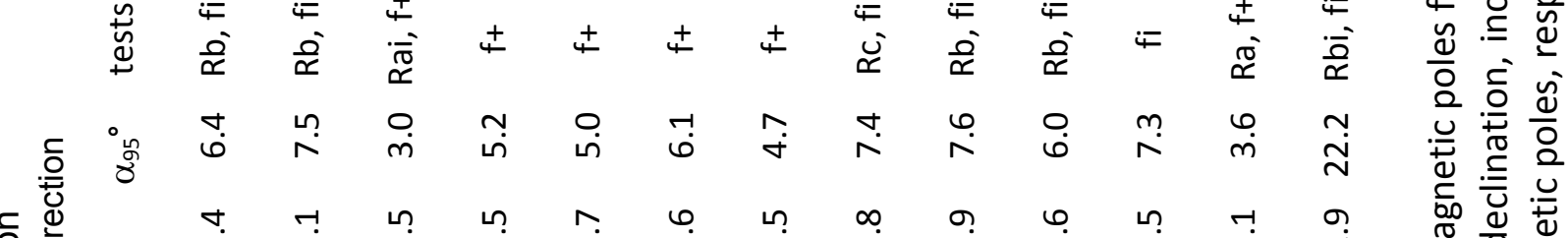

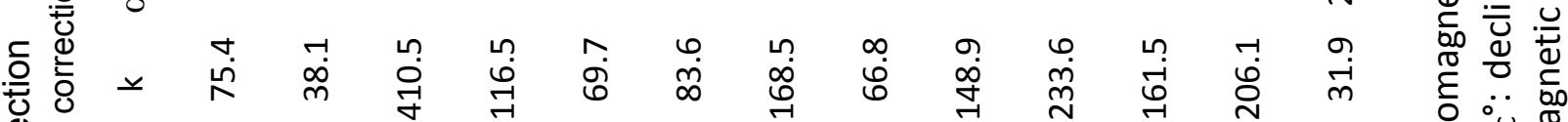

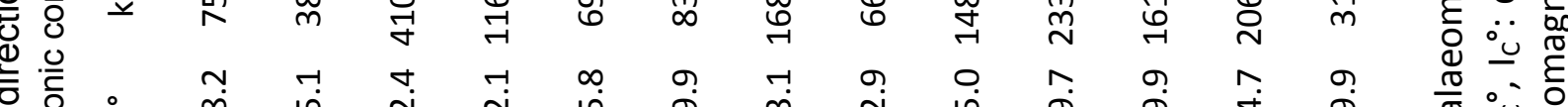
艺 c

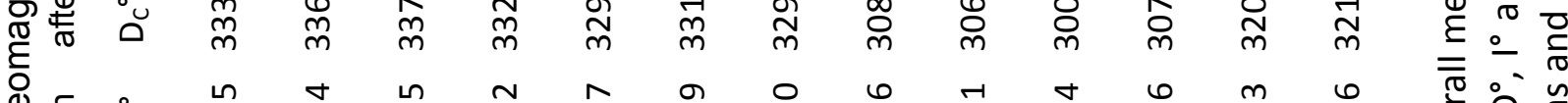

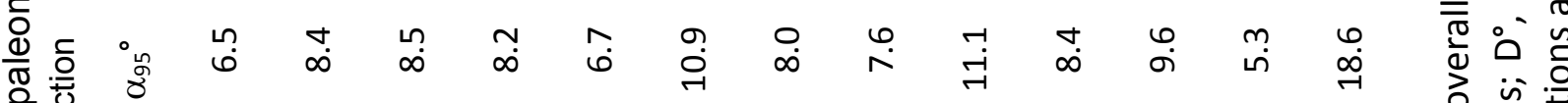
ॠ匚

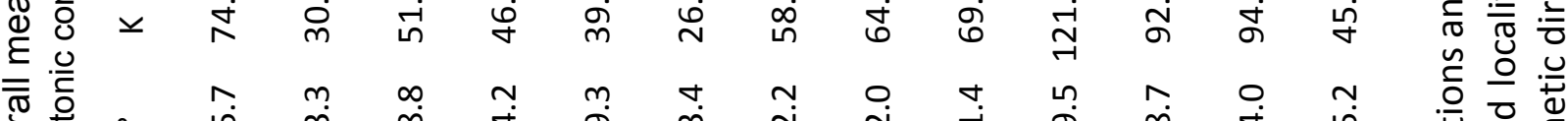
离 产

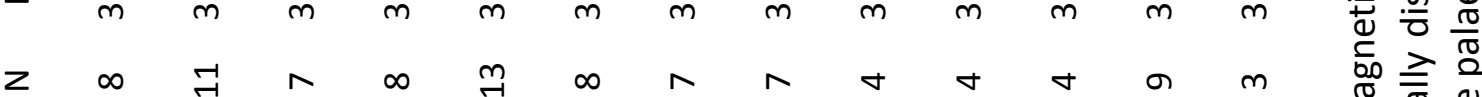

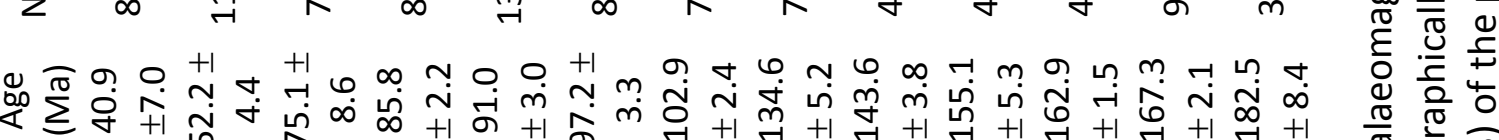

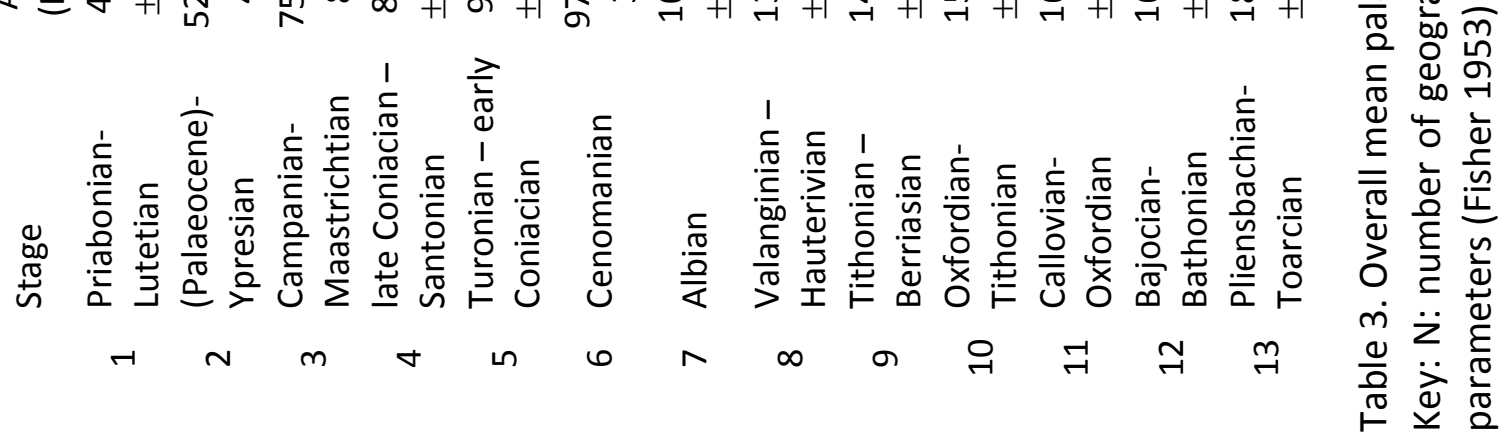





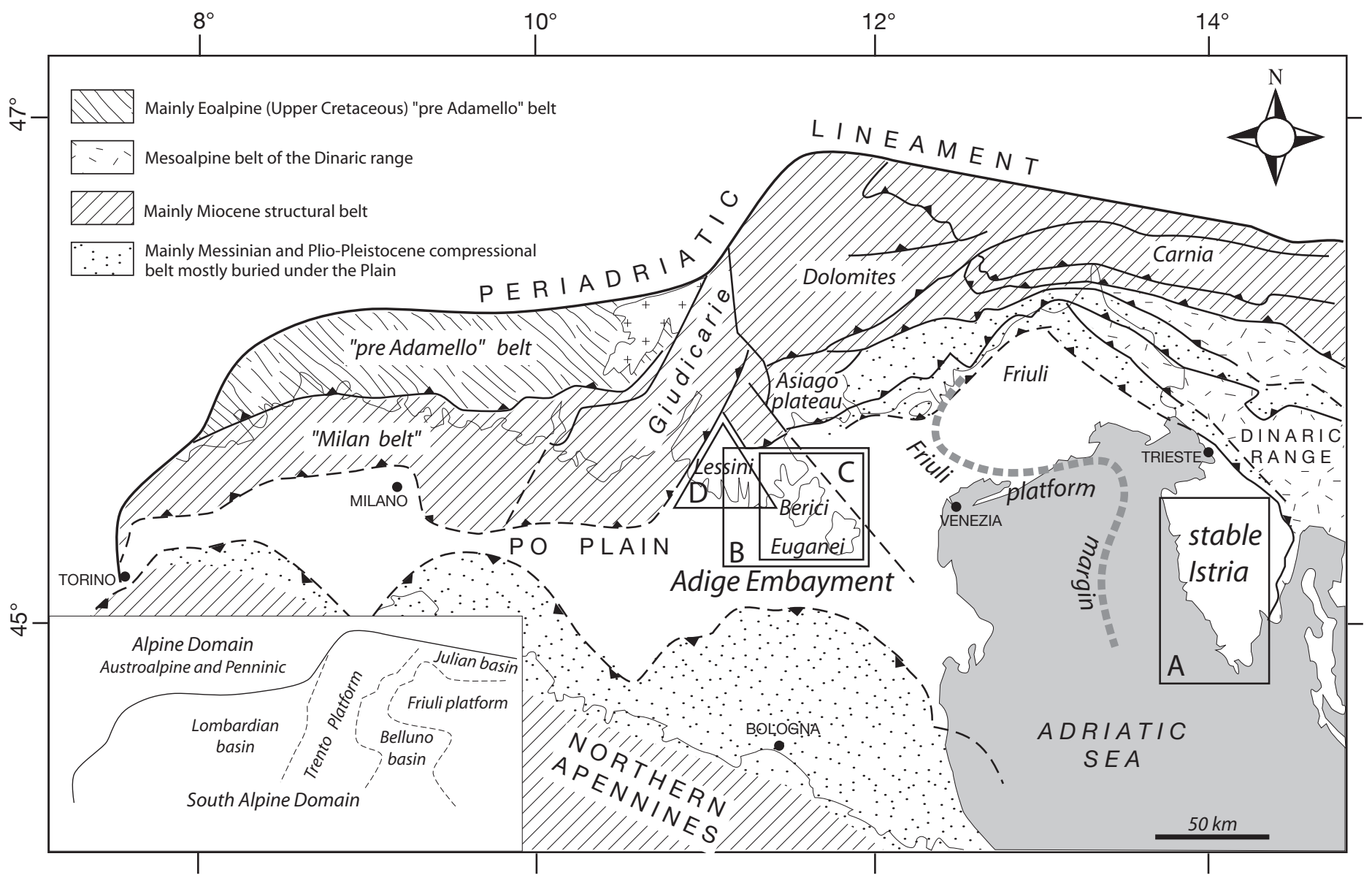

Fig. 1. Structural sketch of the Southern Alps, Northern Apennines and Northern Dinaric range with their partly common foreland areas (modified after Castellarin et al., 2006). The rectangles A to C represent the areas object of our former paleomagnetic studies of the Adria core (Stable Istria and Adige embayment), while the triangular area $D$ represents the sampled area of this work. A is the area where Late Jurassic and Cretaceous rocks were sampled (Márton et al., 2008), $B$ is the area where Cretaceous rocks were sampled (Márton et al., 2010), $C$ is the area where Paleogene and Neogene rocks were sampled within the Adige embayement (Márton et al., 2011), while the Eocene sampled localities from Istria (Márton et al., 2003) are situated in area A. The inset shows the main Mesozoic paleogeographic elements, still preserved in the South Alpine domain. 


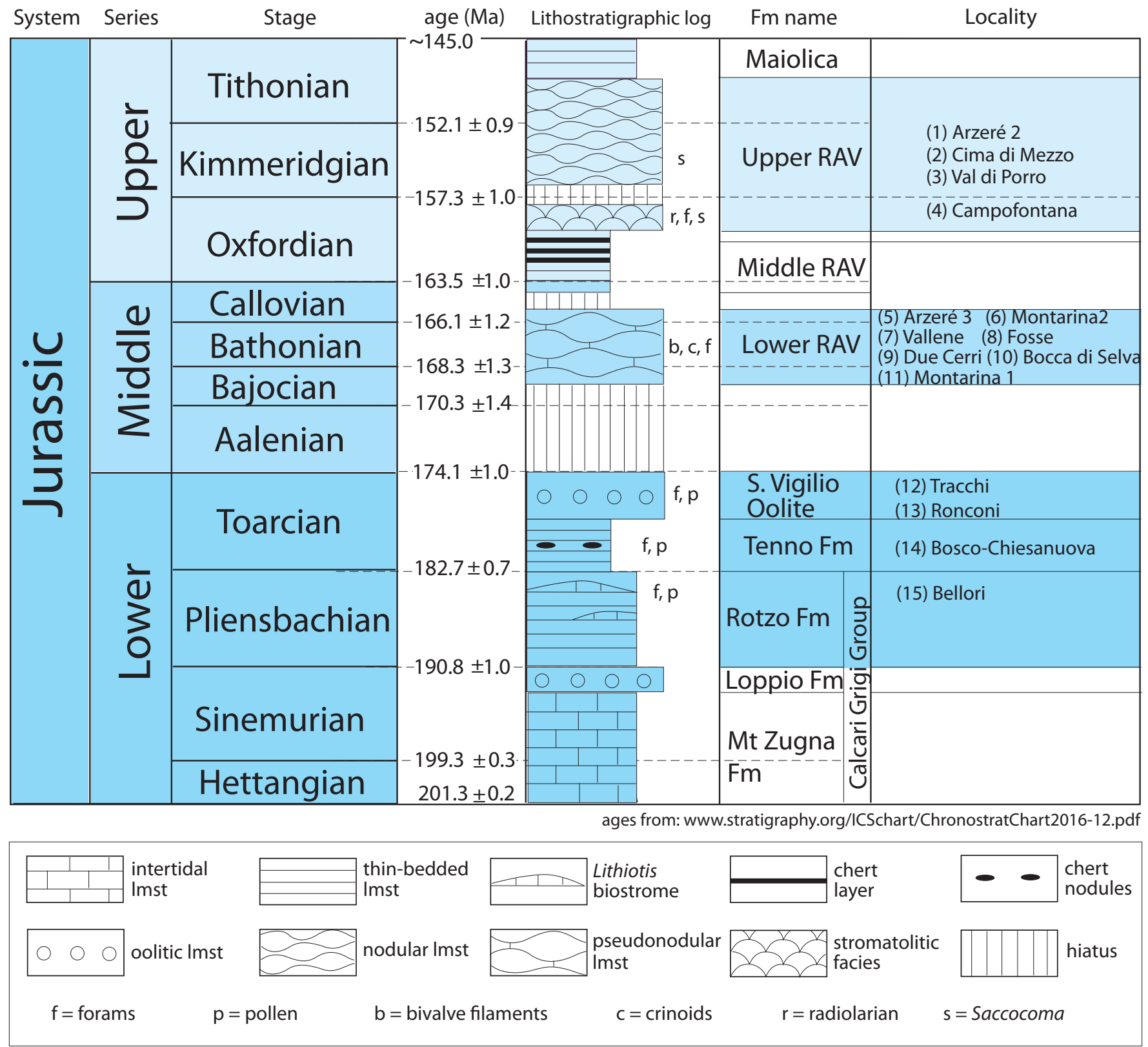

Fig. 2. Chronostratigraphic scheme of the Jurassic (after Cohen et al., 2013, updated) with the lithostratigraphic sketch of the Lessini Mountains and the sampled localities. 


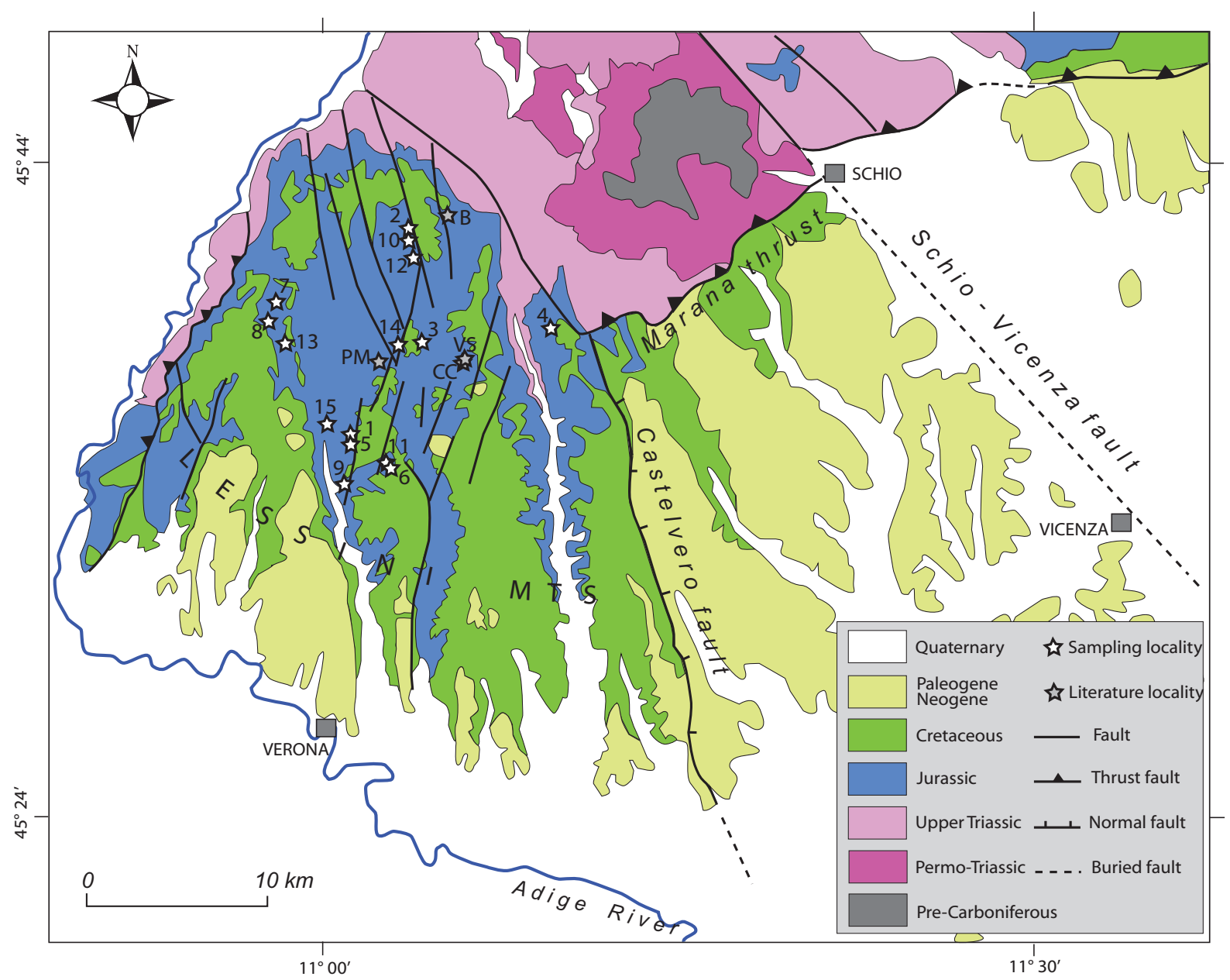

Fig. 3. Simplified geological map of the study area with the paleomagnetic sampling localities of the present study (1-15, the numbers are used throughout the text tables and figures) and earlier published Jurassic localities, which are the followings: $B=$ Branchetto (Muttoni et al., 2013), $\mathrm{PM}=$ Piccola Mantova II, CC = Covolo di Camposilvano, VS = Valle delle Sfingi (Channell et al., 1990). 


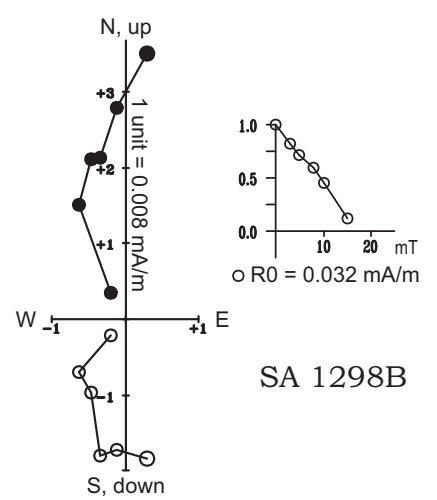

SA $1228 B$

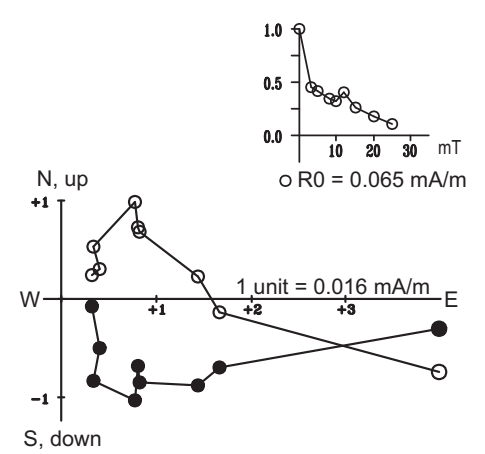

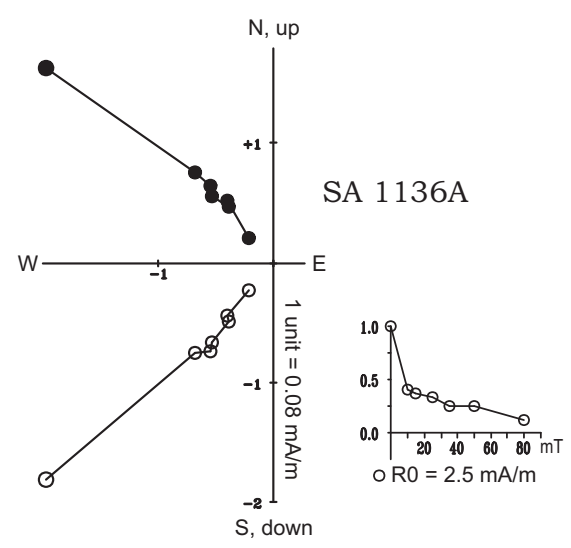

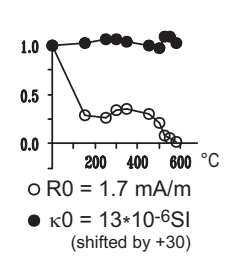

SA $1251 B$

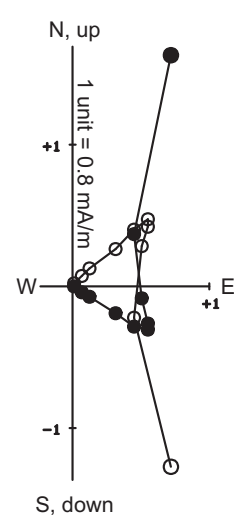

SA $1310 B$
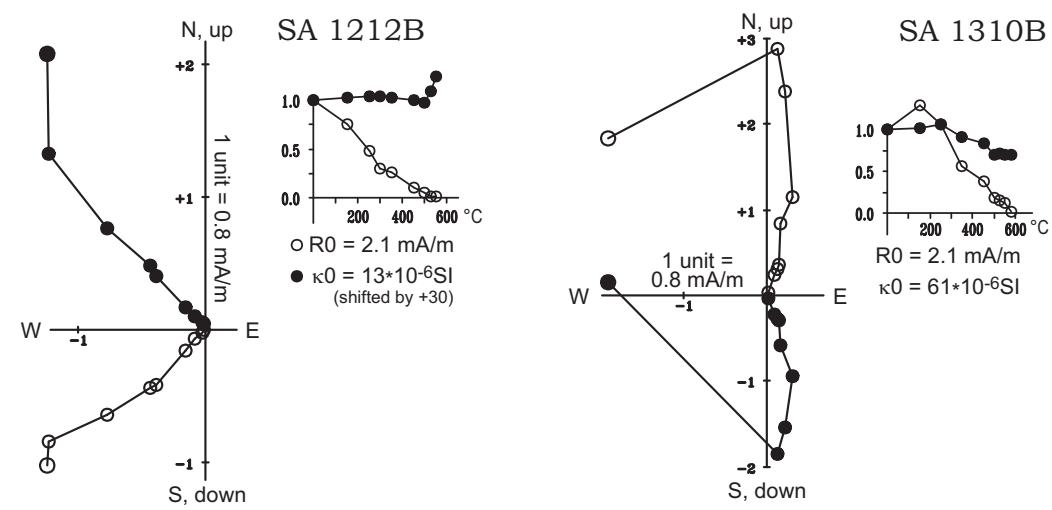

Fig. 4. Typical demagnetization curves for Lower Jurassic platform carbonates (specimens SA1298B and 1228B), for Middle Jurassic RAV (specimens 1136A and 1212B) and for Upper Jurassic RAV (specimens 1251B and 1310B). Key: Zijderveld diagrams are in the geographic system and are accompanied by intensity (circles) versus demagnetizing field diagrams, when the method of demagnetization is AF, and by NRM intensity (circles) / susceptibility (dots) versus temperature diagrams, when the method of demagnetization is thermal. In the Zijderveld diagrams full dots are the projections of the NRM vector onto the horizontal, circles: into the vertical. 


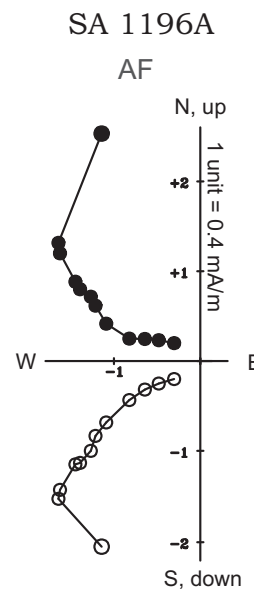

SA $1196 B$

SA $1202 A$

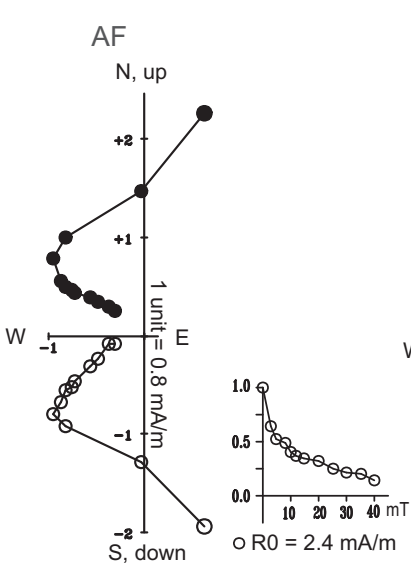

SA $1202 B$

$\mathrm{TH}$
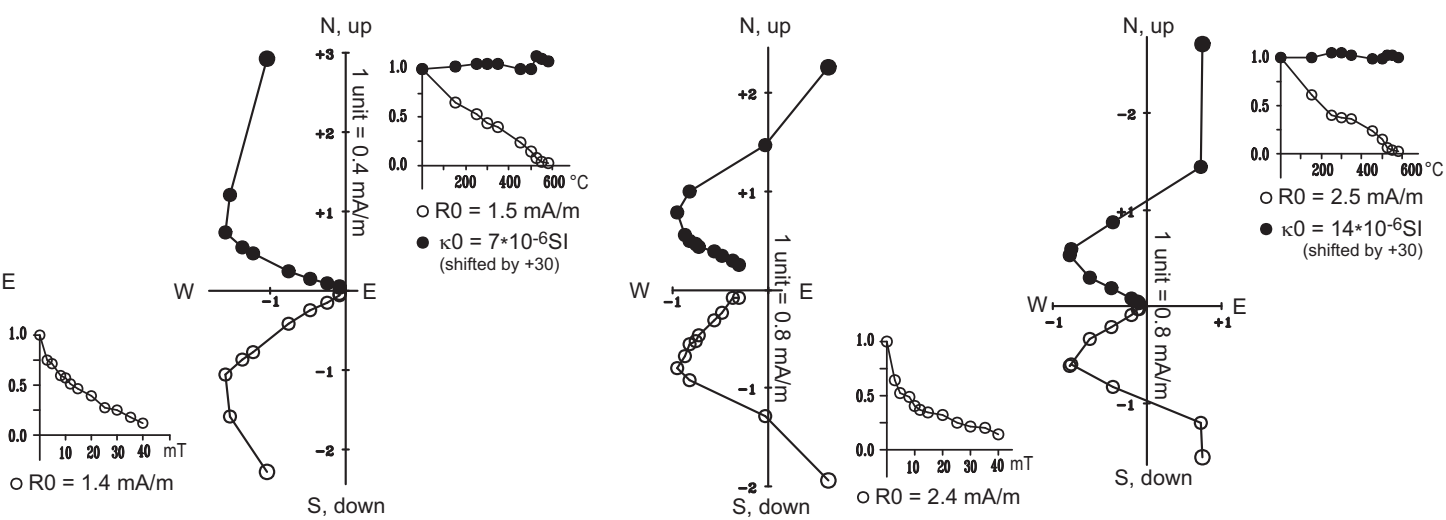

$\mathrm{N}$, up
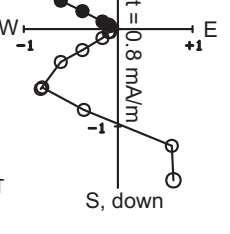

Fig. 5. Behaviour of the NRM on AF and thermal (TH) demagnetizations, respectively of sister specimens of white (sample SA1196) and red (sample SA1202) from the working quarry of Cima di Mezzo (locality 2). Key as for Fig 4. 


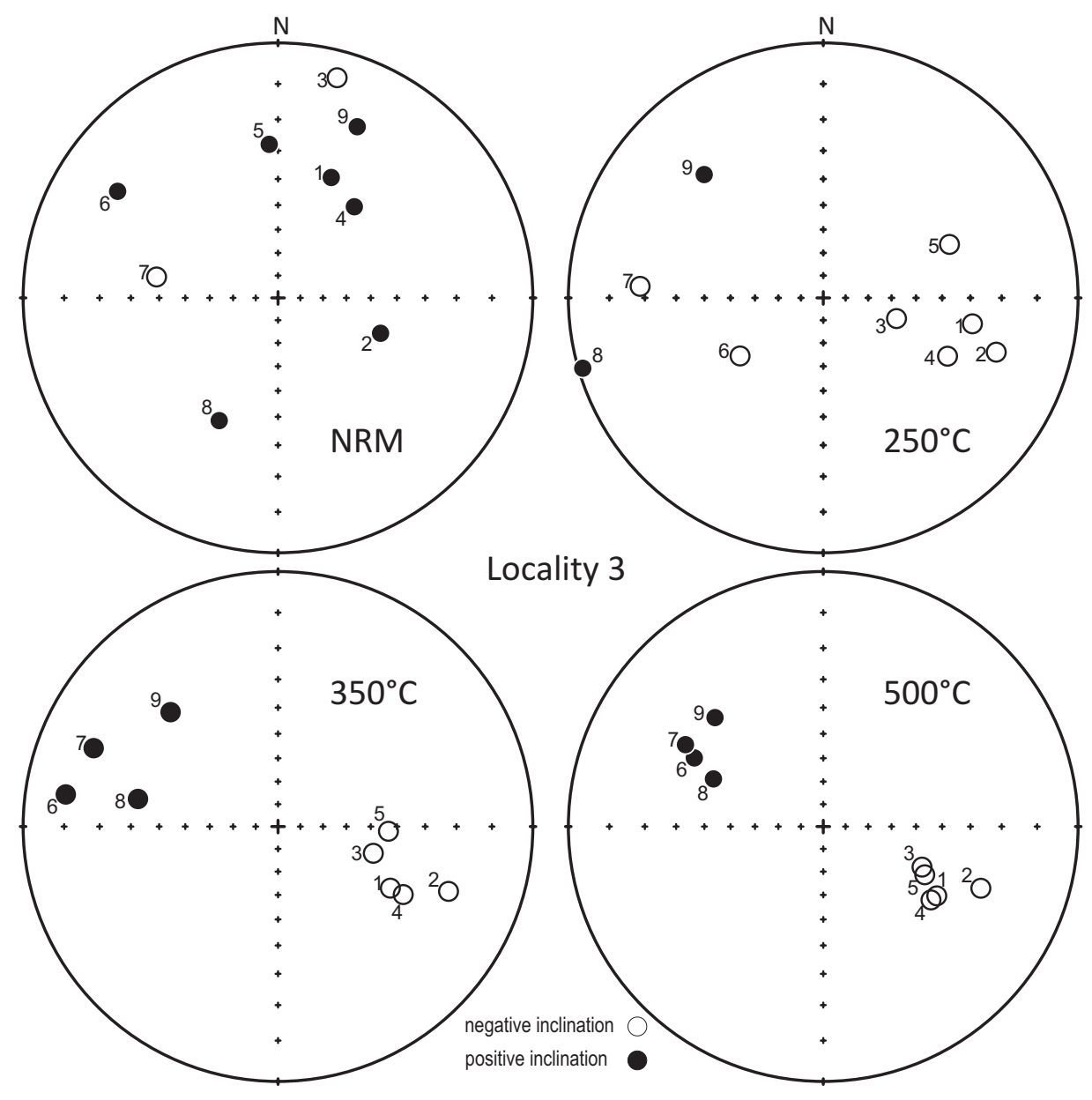

Fig. 6. Example for scattered NRM directions before thermal cleaning (NRM) and the efficiency of the stepwise thermal demagnetization in obtaining antipodal paleomagnetic directions (at $500^{\circ} \mathrm{C}$ ). White samples representing two beds have reversed, red samples from one bed have normal polarity characteristic remanence. 


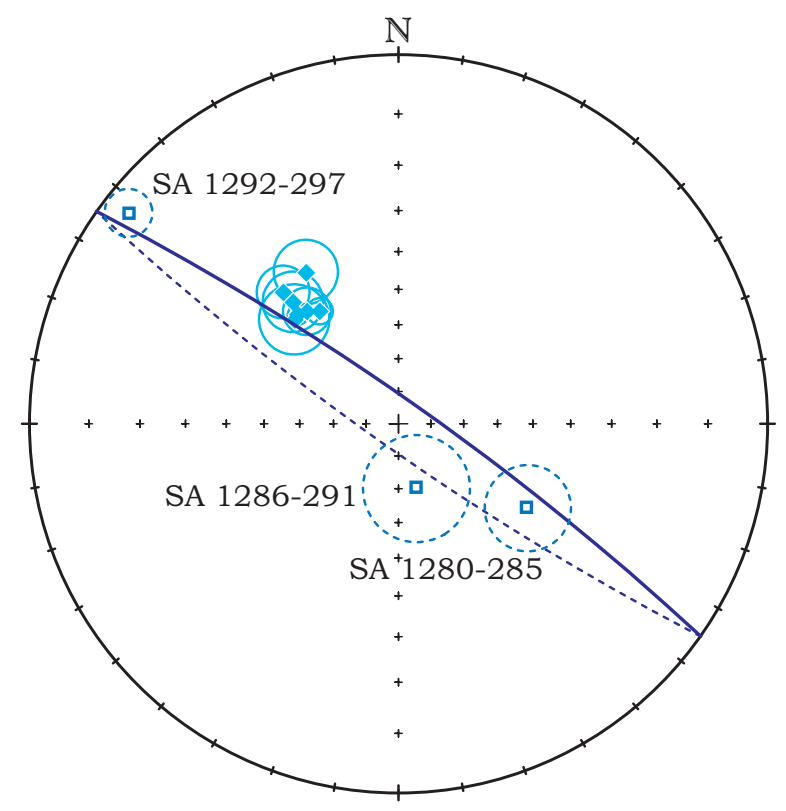

Fig. 7. Great circle distribution of ChRMs obtained for three points distributed in different parts of a huge quarry (locality 7 ). The great circles passes very close to the locality mean directions of localities 5 , 6, 8-11 (Table 1). Key: full symbols positive, empty symbols negative inclinations. 

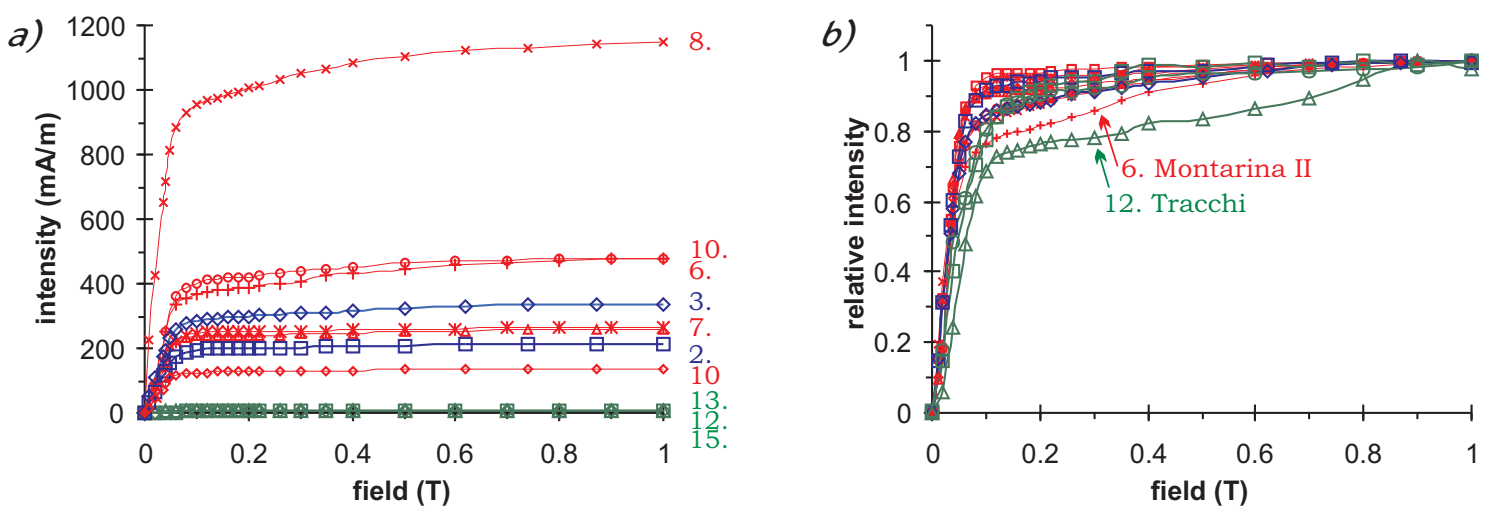

Fig. 8. Isothermal remanence (IRM) acquisition curves for Lower Jurassic platform carbonates (curves 12, 13 and 15), for Middle Jurassic RAV (curves 6, 7, 810 , two curves from the same locality are shown when the samples of different colours have significantly different max. IRM intensities, namely white ones exhibit the lower, red ones the higher values) and for Upper Jurassic RAV (curves 2 and 3). The vertical axis of the 8a diagrams show the intensity of the IRM, that of the $8 \mathrm{~b}$ diagrams the intensities normalized to the highest value. 

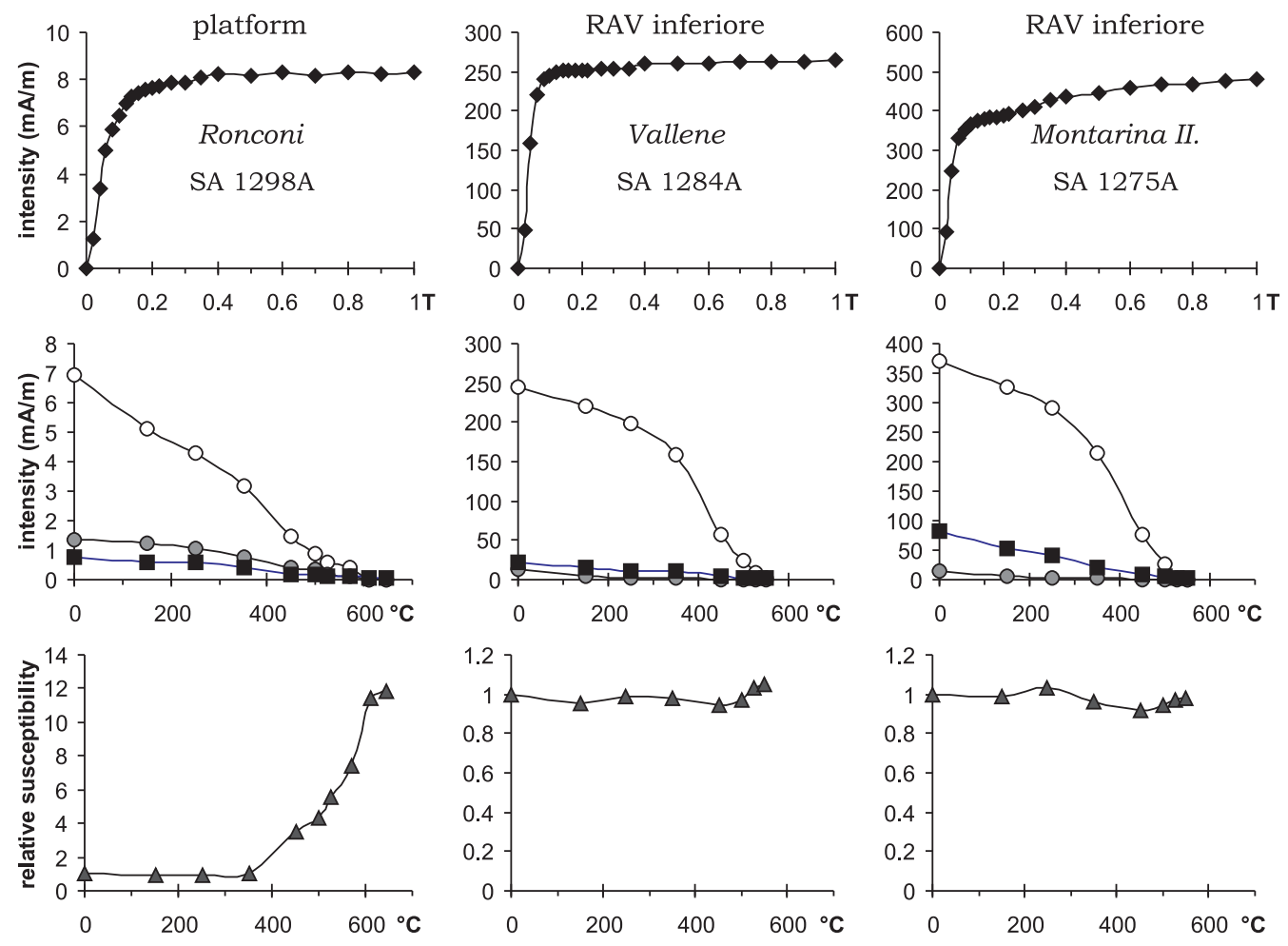

Fig. 9. Examples of the IRM acquisition (uppermost row), behaviour of the 3-component IRM (middle row) and the magnetic susceptibility (lowermost row) on stepwise thermal demagnetization. Key to the 3-component IRM: soft (circles), medium hard (dots) and hard (triangles) component, aquired in $0.12,0.36$ and $1.0 \mathrm{~T}$ fields, respectively. 
a)

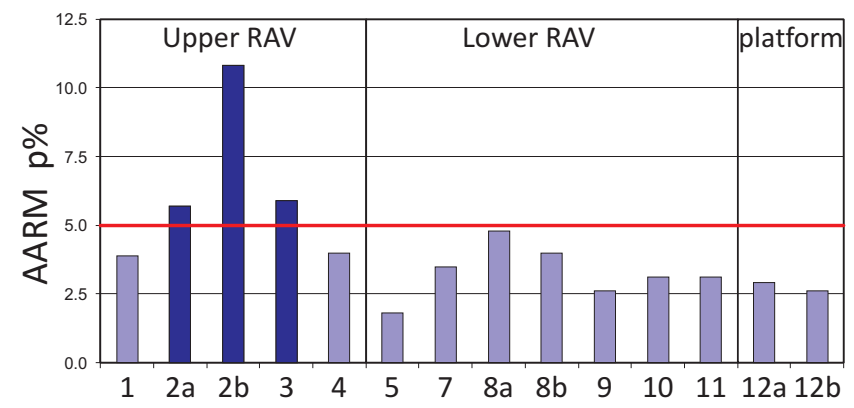

b)

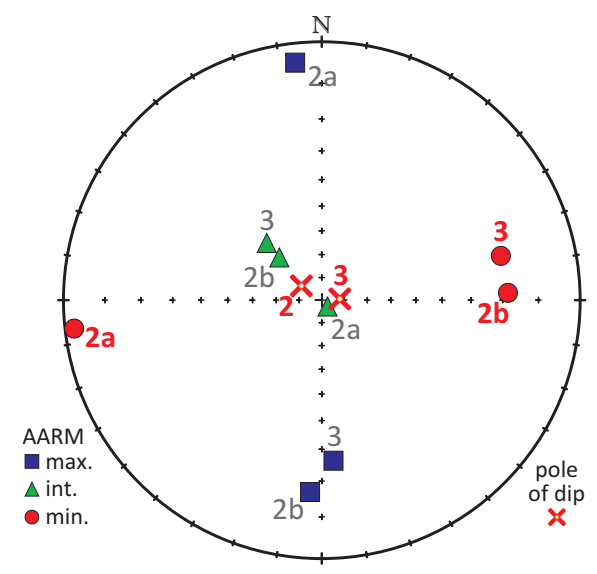

Fig. 10. AARM experiments suggesting that correction for inclination flattening is not needed. Fig. 10a shows the degree of AARM for the different localities. For locality 2, it is higher for the red (locality $2 b$ ) than for the white (locality 2a) limestones from the same loclality. Note that the degree of AARM exceeds $5 \%$ only for two localities, representing Upper Rosso Ammonitico Veronese (RAV), where the compaction affected the "matrix" between the harder nodules. The lower diagram (10b) is a stereogram documenting that the poles of the magnetic foliations (minima) and the bedding poles (crosses) make nearly $90^{\circ}$. Thus, the possibility of inclination flattening due to compaction is safely excluded even in cases of higher than 5\% AARM 


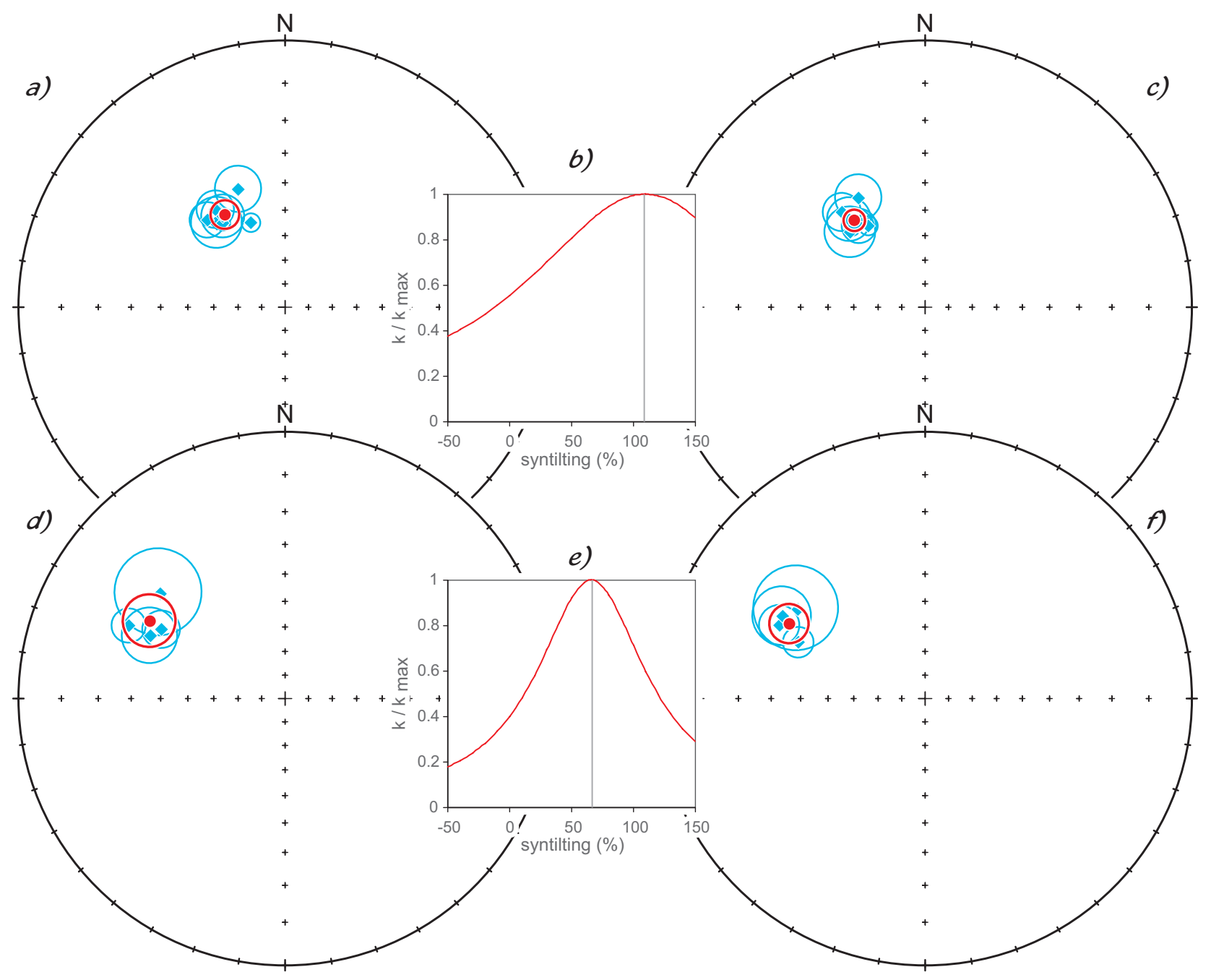

Fig. 11. Tilt tests for the Lower (11a, b and c) and for the Upper (11d, e and f) RAV from the Adige embayment. Locality mean paleomagnetic directions with $\alpha_{95}$ are shown before ( $a$ and $d$ ) and after ( $c$ and $f$ ) tilt corrections. Reversed and mixed polarity paleomagnetic directions are plotted as normal. The overall mean paleomagnetic direction for the Lower RAV is $D=327.2^{\circ}$ $\mathrm{I}=44.4^{\circ}, \mathrm{k}=112.9, \alpha_{95}=5.2^{\circ}$ before and $\mathrm{D}=321.3^{\circ}, \mathrm{l}=44.3^{\circ}, \mathrm{k}=201.2, \alpha_{95}=3.9^{\circ}$, after tilt corrections, the direction correction tilt test (Enkin 2003) is positive. For the Upper RAV the values are $D=301.7^{\circ}, I=29.5^{\circ}, k=122$, $\alpha_{95}=8.4^{\circ}$ before and $D=300.6^{\circ}, l=29.7^{\circ}, k=234, \alpha_{95}=6.0^{\circ}$ after tilt correction. Enkin's test is indeterminate, the McFadden (1990) tilt test excludes the post tilting age of magnetization, but pretilting and syn-tilting age are both possible. Stereographic projections, all vectors are pointing downwards. Between the left and right diagrams the result of the stepwise untilting (b and e) is plotted. 


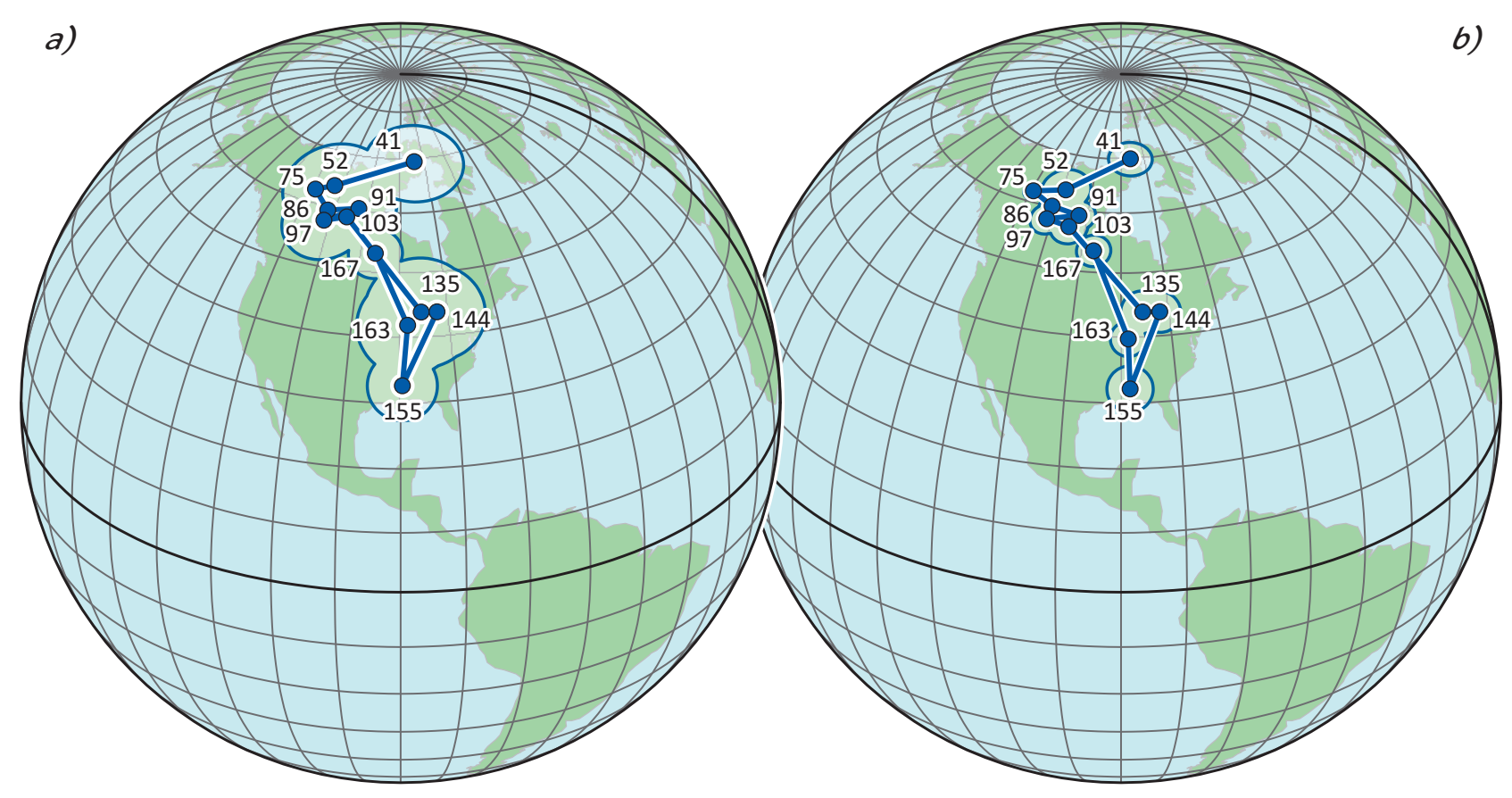

Fig. 12. APW for Adria defined by direct paleomagnetic results from the Adige Embayment and stable Istria. The paleomagentic poles are shown with A95. On Fig. 12a the calculation of the poles and A95 were based on geographically distributed localities, while on Fig $12 \mathrm{~b}$, on independently oriented samples. 

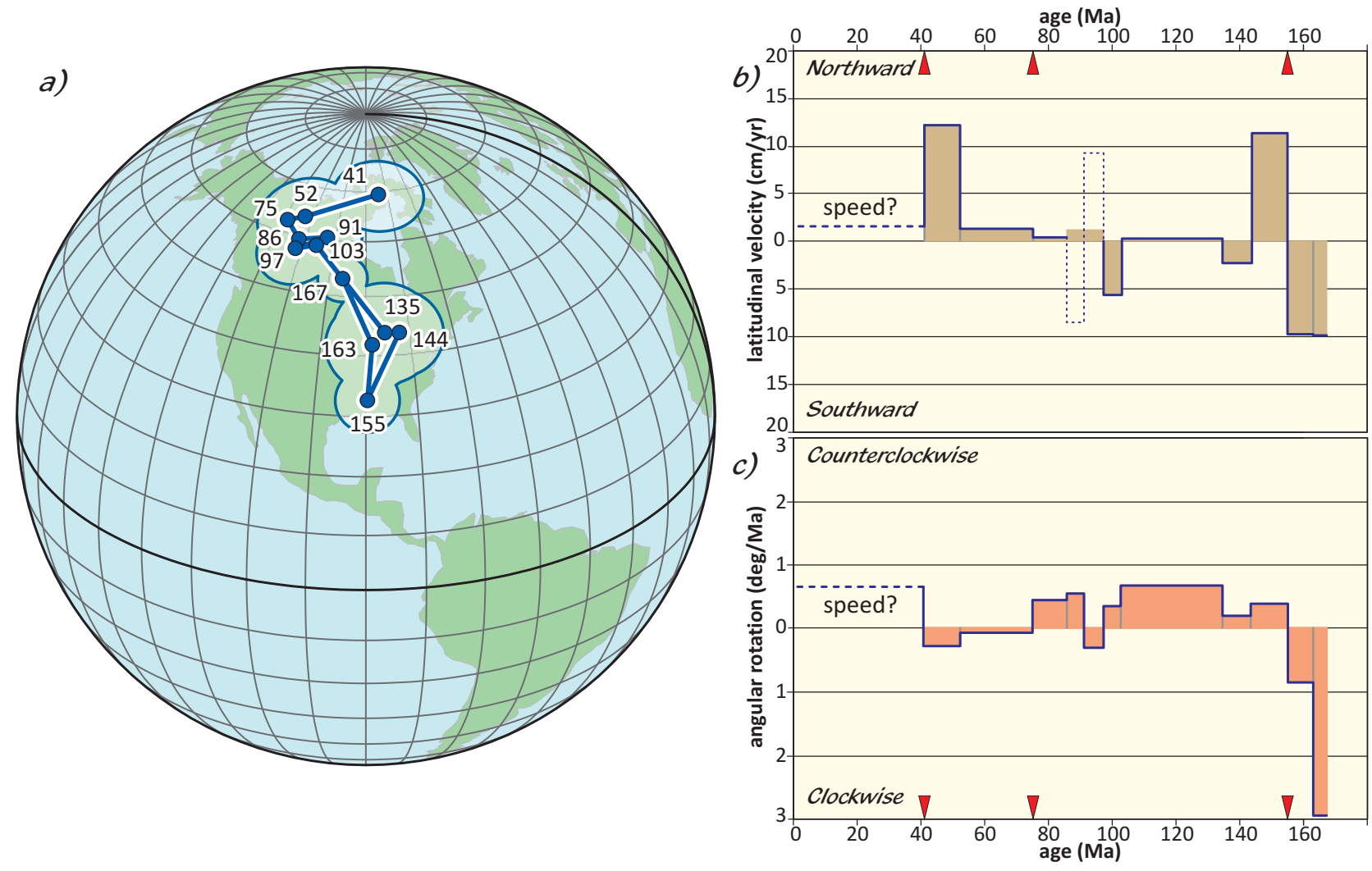

Fig. 13. The APW for Adria (13a), same as on the Fig. 12a and the lattudinal velocities (13b) and angular rotations (13c) calculated from the APW for Adria. 

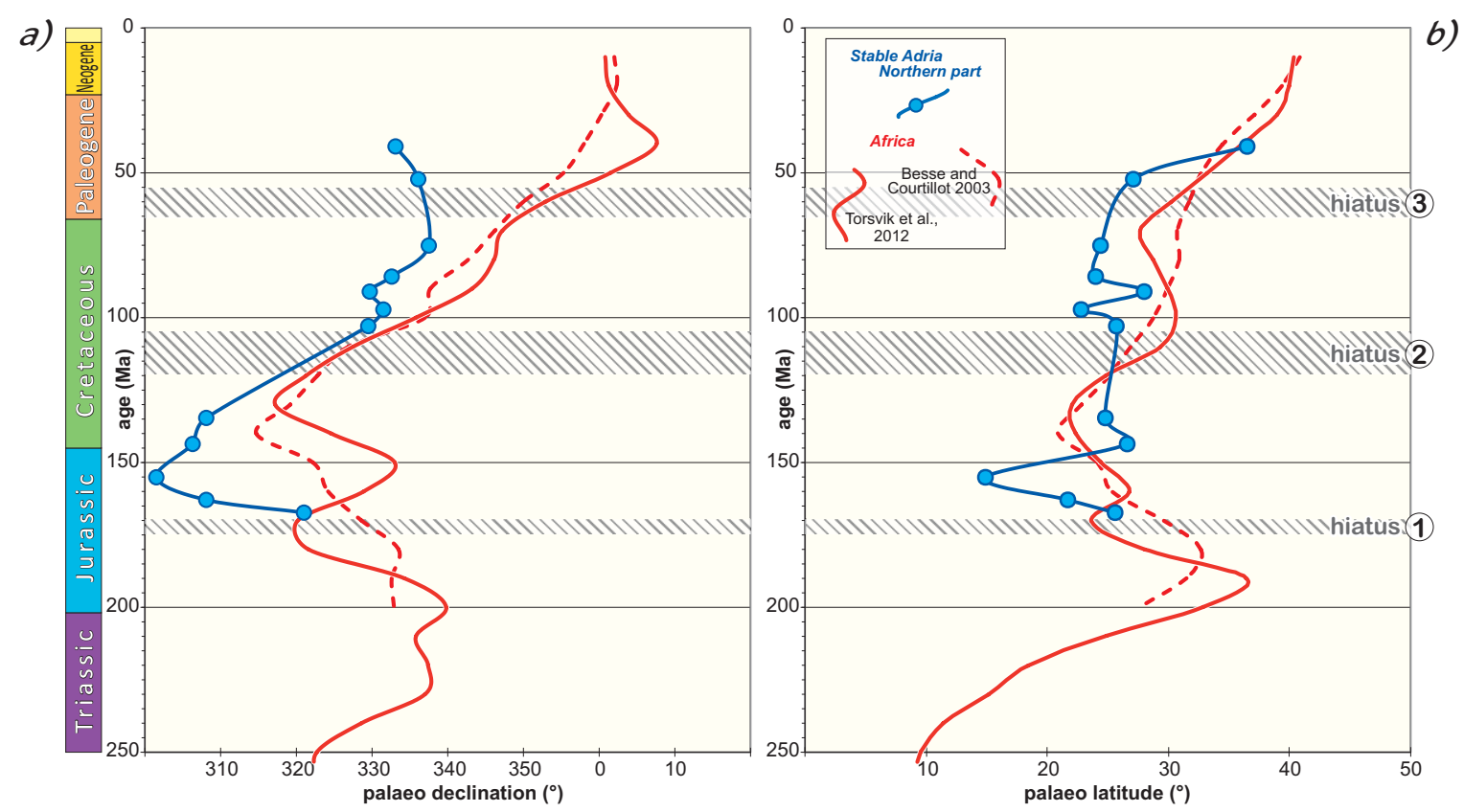

Fig. 14. Comparison of paleomagnetic declinations (14a) and paleolatitudes (14b) from the APW of Northern segment of Stable Adria (Fig. 12a) with declinations and paleolatitudes expected in an African framework from synthetic APWs by Besse and Courtillot (2003) and Torsvik et al., (2012). All data are recalculated for a reference location $45.3^{\circ} \mathrm{N}, 12.5^{\circ} \mathrm{E}$. Stratigraphic gaps longer than $5 \mathrm{Ma}$ are indicated by shaded and numbered intervals. 

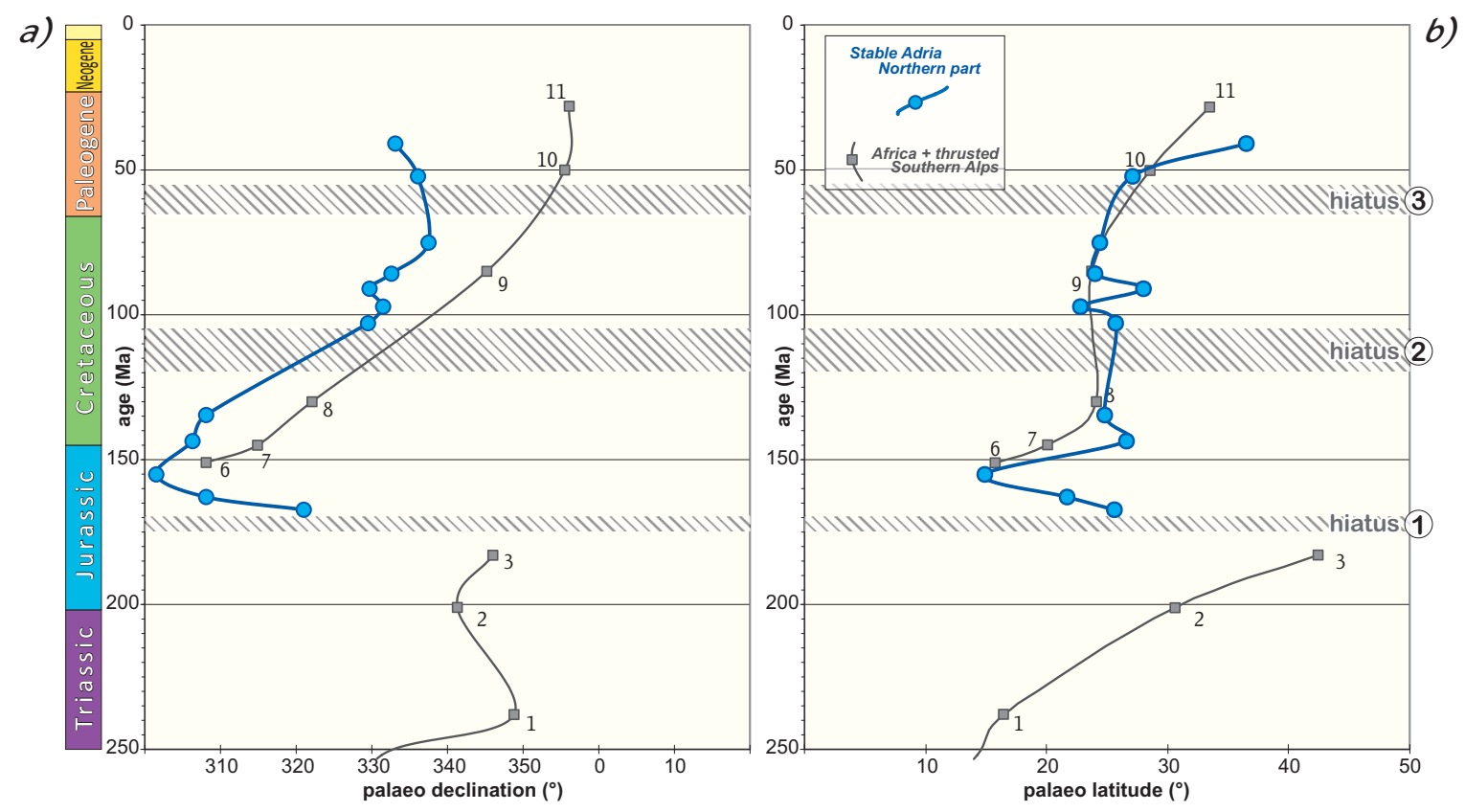

Fig. 15 Comparison of paleomagnetic declinations (15a) and paleolatitudes (15b) from the APW of Northern segment of Stable Adria (Fig. 12a) with those computed for the same co-ordinates from data compiled by Muttoni et al. (2013) for Africa plus the thrusted Southern Alps (numbered). Solely African data are 3 and 11, solely thrusted Southern Alps are 6 and 7, mixed data are 1, 2, 8, 9 and 10. All data are recalculated for a reference location $45.3^{\circ} \mathrm{N}, 12.5^{\circ} \mathrm{E}$. Stratigraphic gaps longer than $5 \mathrm{Ma}$ are indicated by shaded and numbered intervals. 

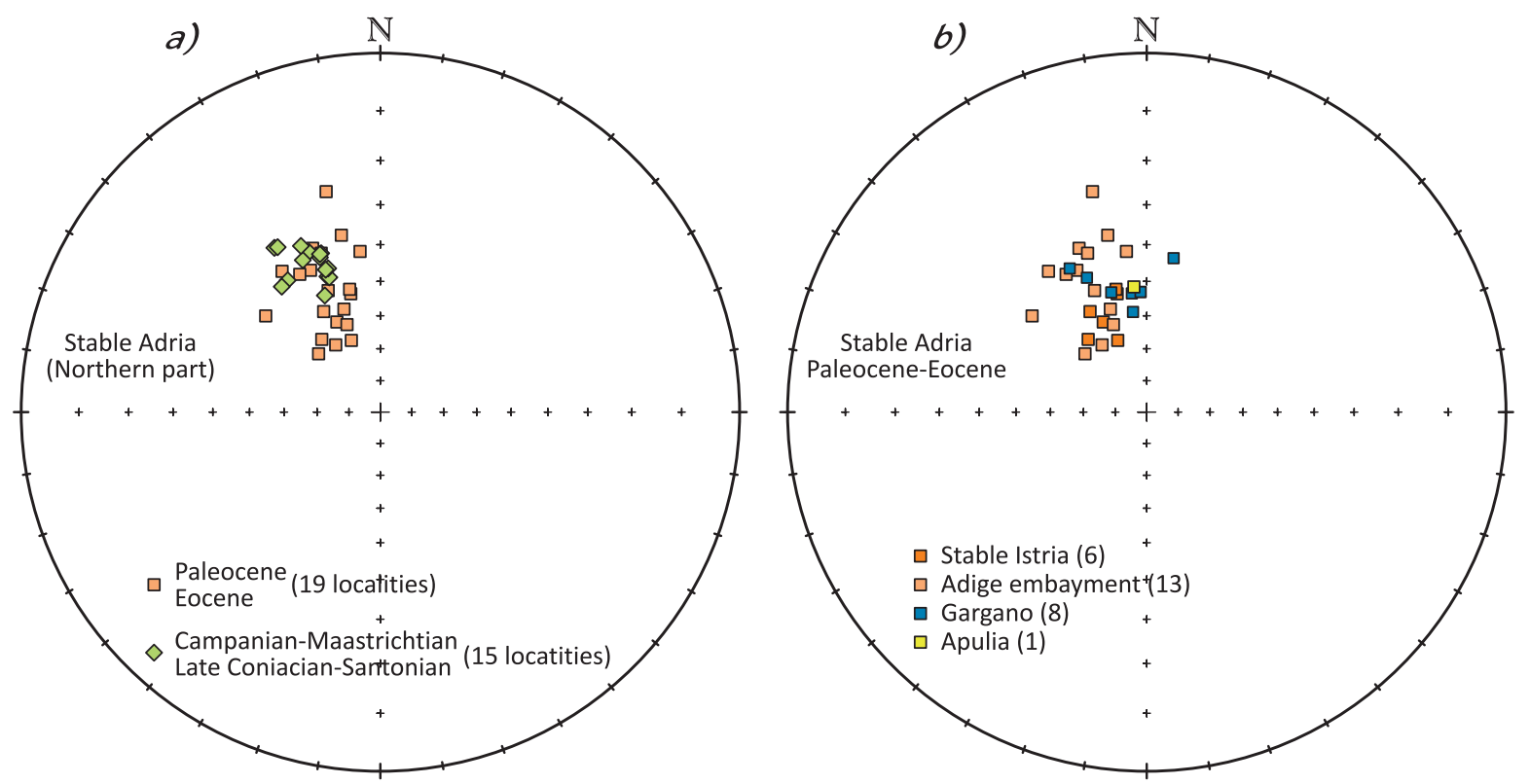

Fig. 16. Locality mean paleomagnetic directions recalculated from the locality mean paleomagnetic poles for a reference location $45.5 \mathrm{~N}, 12.5 \mathrm{E} .16 \mathrm{a}$ Eocene (Paleocene) and Maastrichtian - Santonian from the northern part of stable Adria (data listed in Table 2), documenting that the clusters for the two age groups overlap and 16b for Eocene (Paleocene) from the northern part with Eocene ones from the southern part (data for Gargano are from Speranza and Kissel, 1993 and for Apulia from van Hinsbergen et al., 2014). Based on $16 \mathrm{~b}$ a common overall-mean paleomagnetic direction was calculated for the Eocene (Paleocene).

The figures do not show data interpreted in the original paper as full overprints (Speranza and Kissel 1993, Márton et al., 2003, 2013), and from thrusted Southern Alps (Alano di Piave, Possagno, Cicogna and Adro). 